\title{
Effects of increased paternal age on sperm quality, reproductive outcome and associated epigenetic risks to offspring
}

\author{
Rakesh Sharma', Ashok Agarwal ${ }^{1 *}$, Vikram K Rohra ${ }^{1}$, Mourad Assidi ${ }^{2,3}$, Muhammad Abu-Elmagd ${ }^{2,3}$ \\ and Rola F Turki ${ }^{3,4}$
}

\begin{abstract}
Over the last decade, there has been a significant increase in average paternal age when the first child is conceived, either due to increased life expectancy, widespread use of contraception, late marriages and other factors. While the effect of maternal ageing on fertilization and reproduction is well known and several studies have shown that women over 35 years have a higher risk of infertility, pregnancy complications, spontaneous abortion, congenital anomalies, and perinatal complications. The effect of paternal age on semen quality and reproductive function is controversial for several reasons. First, there is no universal definition for advanced paternal ageing. Secondly, the literature is full of studies with conflicting results, especially for the most common parameters tested. Advancing paternal age also has been associated with increased risk of genetic disease. Our exhaustive literature review has demonstrated negative effects on sperm quality and testicular functions with increasing paternal age. Epigenetics changes, DNA mutations along with chromosomal aneuploidies have been associated with increasing paternal age. In addition to increased risk of male infertility, paternal age has also been demonstrated to impact reproductive and fertility outcomes including a decrease in IVF/ICSI success rate and increasing rate of preterm birth. Increasing paternal age has shown to increase the incidence of different types of disorders like autism, schizophrenia, bipolar disorders, and childhood leukemia in the progeny. It is thereby essential to educate the infertile couples on the disturbing links between increased paternal age and rising disorders in their offspring, to better counsel them during their reproductive years.
\end{abstract}

Keywords: Paternal age, Infertility, Semen parameters, Reproduction, Genetics, Sperm DNA damage, Telomere length, Aneuploidy, Epigenetics, Offspring, Assisted reproductive techniques

\section{Background}

Increased life expectancy, advanced age of marriage, various socio-economic factors and an overall change in role of women in society has led couples to start their family at a later age. The increased accessibility to assisted reproductive techniques has increased the chance of older parents with poor pregnancy outcomes to conceive children, hence, increasing the average paternal age at first childbirth. In comparison to 1993, the paternal age of English fathers has increased by $15 \%$ in a period of ten years [1]. Increased paternal age affects testicular function [2], reproductive hormones [3], sperm parameters [4,5], sperm DNA integrity

\footnotetext{
* Correspondence: agarwaa@ccf.org

'Center for Reproductive Medicine, Cleveland Clinic, Cleveland, OH, USA

Full list of author information is available at the end of the article
}

[6], telomere length [7], de novo mutation rate [8], chromosomal structure [6,9] and epigenetic factors [10].

These changes negatively affect fertility and reproductive outcomes in older couples, contributing to higher incidences of congenital birth defects [11] and fetal deaths [12]. Increasing male age has also been shown to be associated with numerous disorders like achondroplasia [13], autism [14], schizophrenia and bipolar disorders, [14] among many others. In this review article, we will elaborate on the effects of increasing paternal age at the molecular level as well as examine their implications on clinical outcomes. We hope to raise awareness among both clinicians and older couples to the risks associated with delayed fatherhood, which may compromise their parenthood dreams as well as their quality of life. 
Testicular functions and reproductive hormones

Several studies in previous years have shown association between testicular functions and advancing age [2,15-19]. Handelsman et al. reported a negative association between increasing paternal age and reduction in testicular volume for men $>80$ years [2]. They also reported a reduction in the size of testis [17]. In a study conducted by Mahmoud et al. it was found that compared to the age group 18-40 years, men aged $>75$ years had $31 \%$ smaller mean testicular volume. Decreased testicular volume is attributed to the decrease in number of Sertoli cells [15]. In addition, Johnson et al. reported the thickening of basal membrane of seminiferous tubules with age [16]. Disturbance in blood supply in senile testis were associated with negative changes in terms of hernia-like protrusions, spermiogenesis and thickness of basement membrane [18].

Increased FSH serum levels and decreasing testosterone levels are the most common clinically relevant alterations associated with male ageing [20]. The decreasing testosterone levels in aging men are linked to andropausal symptoms, such as poor libido, fatigue and loss of cognitive function [21]. Both male sexual function and sexual frequency decrease with age [22-24] and the infertility experienced by many older men may in part be related to the decline in sexual activity.

Leydig cells are responsible for testosterone production. The number of Leydig cells tends to reduce with increasing paternal age [19]. Neaves et al. reported that the average total number of Leydig cell nuclei decrease by half in age group of 50-76 years compared to age group of 20-48 years [19]. Reduced number of Leydig cells plays a key role in incidence and pathogenesis of andropause in aging men [25]. The decreased number of Leydig cells also contribute to reduced levels of total testosterone [26] and free testosterone (1.2\%) serum levels in paternal group $>50$ years.

$\mathrm{Wu}$ et al. reported that age-affected testicular atrophy is a result of Hypothalamic-Pituitary-Testicular (HPT) Axis alterations that disturb the functions of various reproductive hormones [27]. Advanced paternal age has also been associated with changes in different hormonal levels. Table 1 summarizes the effect of increasing paternal age on reproductive hormones.

\section{Sperm parameters}

Semen analysis is an important first step in the laboratory evaluation of the infertile male. It includes the assessment of the ejaculate volume, sperm concentration, motility, and morphology using WHO criteria [34]. Some studies have shown that with increasing paternal age, semen volume, sperm motility, and the percentage of normal morphology tend to decrease $[4,35]$.

With the introduction of the new 2010 WHO guidelines [36], the normal reference range reported at fifth centile has changed for many of the semen parameters. These include: ejaculate volume from $\geq 2 \mathrm{~mL}$ to $1.5 \mathrm{~mL}$; sperm concentration (from $\geq 20 \times 10^{6} / \mathrm{mL}$ to $15 \times 10^{6} / \mathrm{mL}$ ), Total sperm count from $\geq 40 \times 10^{6}$ to $39 \times 10^{6}$; percent motility (from $\geq 50 \%$ to $40 \%$ ); progressive motility from $\geq 25 \%$ (grade a) to $32 \%$ (grade a); morphology (percent normal forms) from $14 \%$ according to strict criteria to $4 \%$; vitality (\% alive) from $30 \%$ to $25 \%$; for performing viability test in semen specimens with poor motility. One of the main features of the new guidelines is the inclusion of the reference ranges and the limits which are significantly lower than those reported in the earlier manuals. It also included data from over 1900 men who recently fathered a child within one year of trying to initiate a pregnancy. However there is much controversy regarding the new reference values and the impact in the management of male infertility [37]. The American Urology association recommends that the initial evaluation should include a reproductive history, and two properly performed semen analysis, followed by extended evaluation if semen parameters are abnormal in the initial evaluation [38]. On the other hand the European Association of Urology (EAU) recommends undertaking male examination if the semen analysis is abnormal [39]. The impact of increasing paternal age as reflected in the semen parameters according to the new criteria remains to be seen and interpreted with caution.

Table 1 Effect of advancing paternal age on reproductive hormones

\begin{tabular}{|c|c|c|c|}
\hline Name of the hormone & Levels & Type of study & Reference \\
\hline Dehydroepiandrosterone (DHEA) & $\downarrow$ & Longitudinal & {$[28]$} \\
\hline Dihydrotestosterone (DHT) & No Change & Longitudinal & [3] \\
\hline Estrogen & $\downarrow$ & Cross-Sectional & {$[29]$} \\
\hline Follicle-stimulating hormone (FSH) & $\uparrow$ & Longitudinal & {$[3,19,20,30,31]$} \\
\hline Gonadotropin-Releasing Hormone (GnRH) & $\downarrow$ & Animal & {$[32]$} \\
\hline Luteinizing hormone (LH) & $\uparrow$ & Longitudinal & {$[3]$} \\
\hline Sex hormone-binding globulin (SHBG) & $\uparrow$ & Cross-Sectional & {$[26]$} \\
\hline Testosterone & $\downarrow$ & Longitudinal & {$[3,19,21,33]$} \\
\hline
\end{tabular}


Several mechanisms have been proposed to explain how aging in males may cause changes in semen parameters [40]. These changes can be related to seminal vesicle inadequacy which reduces semen volume or changes in prostate, in terms of prostate atrophy such as reduction in water and protein content which might affect sperm motility and ejaculate volume [40]. Kidd et al. also reported that increasing paternal age is correlated with decrease in ejaculate volume, sperm morphology and motility but not with sperm concentration [40]. Comparing two age groups (30y vs. 50y), a significant difference was reported in semen volume $(3 \%-22 \%)$, sperm motility (3\% - 37\%) and morphology (4\% - 18\%) [40]. In a study conducted by Hossain et al. it was reported that with increasing paternal age, both sperm volume and sperm count decreased [41]. Similarly, in a large prospective study comprising of 3,729 male partners evaluated for semen quality and age-specific changes, a significant decrease was reported in sperm volume and motility with increasing paternal age [42].

Sperm samples from 5081 men aged between 16 and 72 years were examined for effects of male age on semen parameters [43]. Deterioration in sperm quality and quantity after age 35 was reported with declining probability of pregnancy following intercourse with men $>34$ years old, when women age factor was eliminated [43]. Another recent study investigated the effects of paternal age on DNA fragmentation, semen quality and chromosomal aneuploidies [4]. Spermatozoa from 140 infertile men between 24-76 years of age and 50 fertile men age group (25-65 years) were examined. The findings of the study illustrated that with increased male age, semen volume and vitality decreased while sperm concentration and diploidy increased [4]. However, no significant difference in the motility, morphology and DNA fragmentation was reported with increasing male age [4].

Similarly, in another study the correlation of men's age with semen quality and seminal levels of epididymal and accessory gland markers were examined. A statistically significant decrease in semen parameters was reported in men aged 35 years and particularly with those over 46 years. This was associated with an increase in the percentage of dead spermatozoa [44]. Semen samples collected from men aged between 30 years to 40 years showed semen parameters to be inversely related to men's age. Several other retrospective studies have shown a relation between sperm parameters and age and reported lower semen volume, lower progressive motility and percentage of normal morphology in older men compared to younger men [45-47].

\section{Age threshold}

As mentioned earlier, it was reported that the sperm parameters do not change until males reach the age of 34 years [40]. In a study by Kidd et al. [40], the total sperm count was the first parameter to be affected immediately after a person crossed the 34 year threshold. Sperm concentration as well as the percentage of sperm with normal morphology declined at the age of 40. Sperm motility and semen ejaculate volume declined at the age of 43 years and 45 years respectively [43]. Another study conducted in China examined the semen analysis of 20-60 years old men and showed that age was negatively correlated with progressive motility, vitality, and percentage of normal sperm. Rapid progressive motility and percentage of normal sperm morphology began to decline gradually at age 30 years, and progressive motility began to decrease at age 40 years [48] and defective sperm function [49]. The variation in the results of these studies could be due to the differences in the type of study (prospective versus retrospective) [50]. The variation of results in different studies could be related to sexual abstinence time which was different along with many other factors such as type of study, different age groups, sample size and different ethnicities, biological variability and the fact that semen parameters are poor predictors of male fertility potential $[51,52]$. A compilation of some of the recent studies and their findings related to different sperm parameters is shown in Table 2.

Table 2 Effect of paternal age on different sperm parameters

\begin{tabular}{|c|c|c|c|c|c|c|}
\hline \multirow{2}{*}{$\begin{array}{l}\text { Type of } \\
\text { study }\end{array}$} & \multirow{2}{*}{$\begin{array}{l}\text { Age } \\
\text { grouping }\end{array}$} & \multicolumn{4}{|c|}{ Effects on sperm parameters } & \multirow[t]{2}{*}{ Reference } \\
\hline & & Concentration & Morphology & Motility & Ejaculate volume & \\
\hline \multirow[t]{5}{*}{ Prospective } & $24-76$ & $\uparrow$ & $\downarrow$ & $\downarrow$ & $\downarrow$ & {$[4]$} \\
\hline & $22-80$ & $\downarrow$ & - & $\downarrow$ & $\downarrow$ & {$[46]$} \\
\hline & $22-80$ & - & - & $\downarrow$ & - & {$[50]$} \\
\hline & & & & $\begin{array}{l}\text { All CASA parameters of motility except amplitude } \\
\text { of lateral head displacement and beat cross frequency }\end{array}$ & & \\
\hline & $30-50$ & - & $\downarrow$ & $\downarrow$ & $\downarrow$ & {$[40]$} \\
\hline Retrospective & $25-55$ & - & - & $\downarrow$ & $\downarrow$ & {$[41]$} \\
\hline Prospective & Not specific & - & Not measured & $\downarrow$ & $\downarrow$ & {$[42]$} \\
\hline
\end{tabular}




\section{Genetics of male aging DNA fragmentation}

Some of the potential causes of DNA damage in sperm are abnormal protamination or abnormal protamines compaction [53-55]. It is attributed to the presence of histones $(15 \%)$ that are not converted into protamines and result in altered $\mathrm{P} 1 / \mathrm{P} 2$ ratio in infertile men, protamine deficiency [56-60]. Oxidative stress as a result of increased production of reactive oxygen species or reduced antioxidant reserves is responsible for a majority of DNA fragmentation (almost 80\%) seen as a result of infection, inflammation or in cases of various clinical diagnosis of male infertility [61-73]. DNA fragmentation as a result of single or double strand breaks can be measured by two common methods i.e. sperm chromatin structure assay (SCSA) [74,75], or by the terminal deoxynucleotidyl transferase-mediated dUTP nick end-labeling (TUNEL) assay [76]. TUNEL assay however cannot differentiate between apoptosis and necrosis.

Apoptosis in sperm is different from apoptosis seen in somatic cells where it is regulated at the plasma level (presence of Fas receptors), nucleus (presence of p53 inducing upregulation of Bax gene and down regulation of Bcl-2 expression) and cytoplasm (activation of Bax and release of cytochrome $\mathrm{c}$ and caspase cascade in the cytosol) [77-79]. Ejaculated sperm show features characteristic of apoptosis such as ultrastructural observation of the chromatin, mitochondria, the nuclear envelope, plasma membrane, presence of apoptotic bodies and presence of DNA fragmentation and externalization of phosphatidyl serine residues.

Abortive apoptosis like features in immature/abnormal sperm include remnants of cytoplasm and poor chromatin packaging and/or damaged DNA Abortive apoptosis is initiated during spermatogenesis. Spermatozoa earmarked for elimination escape at ejaculation in what is called abortive apoptosis and contribute to poor sperm quality. This is largely due to the presence of excess cytoplasm present in morphologically abnormal sperm [80-82]. More than $40 \%$ of the cells earmarked to be eliminated were reported to be present on the seminal ejaculate as examined by Annexin V and TUNEL assay [83].

DNA damage can also result from activated PARP and activated caspase3. PARP-1 has been implicated in DNA damage and apoptosis, in addition to its more complex events such as nucleosome binding property that promotes formation of compact, transcriptionally repressed chromatin structures. It is also linked with nuclear restructuring when nucleus is compacted with the introduction of protamines. It activates apoptosis during dramatically increased DNA repair and damage. Cleaved PARP also provides an early marker of detecting apoptosis as cleavage of PARP-1 occurs before DNA fragmentation [84].
DNA damage in ejaculated spermatozoa cannot be explained by apoptosis alone $[80,82]$. DNA damage can also be due to aneuploidy as well as mutations, chromosomal disjunction and meiotic segregation [85-87].

A study conducted by Moskovtsev et al. showed that as the incidence of semen abnormalities increased in infertile men, the extent of DNA damage also increased concomitantly [88]. Many other studies have reported a positive correlation between increasing male age and DNA damage $[6,89]$. Using DNA fragmentation Index (DFI) as an index to measure DNA damage/ fragmentation, Moskovtsev et al. reported that in comparison to age group $<30$, age group which was $\geq 45$ had twice the DFI (15.2\% vs. 32.0\%). DFI levels for 30-35, $35-40$ and $40-45$ were found out to be $19.4 \%, 20.1 \%$ and $26.4 \%$ respectively [6].

Similar results were shown in a study conducted by Singh et al. in which it was shown that the percentage of highly damaged DNA sperm in age group 36-57 years was significantly higher compared to the age group 20-35 years [89]. In another study involving 215 couples, it was shown that sperm DNA damage doubled from paternal age of 25 to 55 years [90]. A positive association was reported between DFI and increasing paternal age [89-91]. In a group of men with normozoospermia, the DFI level increased by $5 \%$ in age group $\geq 40$ compared to age group $\leq 40$. A similar trend was seen in a group of men with oligoasthenoteratozoospermia in which age group of $\geq 40$ had $8 \%$ higher DFI levels compared to age group $\leq 40$ years [89]. Barroso et al. proposed that the association between DNA fragmentation and advanced paternal age is present due to sperm chromatin defects [92].

A recent meta-analysis study comparing 26 studies involving 10,220 subjects, the authors reported a significant negative association of male age with DNA fragmentation [93]. They advocate the routine screening of men with advanced age for DNA fragmentation as well as cautioning patients of the potential risks. Ageing male and its effect on the functional capacity of the sperm as measured by phosphatidyl serine expression have been reported [94]. Significantly higher expression of phosphatidyl serine translocation at the sperm membrane indicative of apoptosis was reported in men $40 \mathrm{y}$ and older. Similarly a trend was also reported in sperm DNA damage and increasing age of the male.

\section{DNA integrity and ART outcomes}

Sperm DNA damage is associated within lower probability of conception and a longer time to conception [90,95,96]. These studies suggest that DNA damage is a better predictor of pregnancy than the conventional semen parameters [95]. Also DNA damage is correlated with lower pregnancy rates in intrauterine insemination and 
conventional IVF but not intracytoplasmic sperm injection (ICSI) lower pregnancy rates [60,97-101]. In a recent study by Nij's and his group, a prospective study consisting of 278 patients who underwent intracytoplasmic sperm injection (ICSI) or in vitro fertilization (IVF) was examined for an association between semen parameters and men's age. No significant influence of male age was reported on the fertilizing capacity [102].

Positive correlations have been reported between an increased sperm DNA fragmentation, reduced motility and ART outcomes leading to lower pregnancy rates and higher miscarriages [103]. Such DNA integrity reduction was shown to be correlated to advanced paternal age (especially for ages beyond 40 years) $[6,89]$, supporting the overall negative effect of ageing fathers on IVF/ICSI success rate and hence ART outcomes $[104,105]$.

Sperm DNA integrity is not only important for successful IVF but also for normal embryonic development. It has been recently shown that the advanced paternal age and its adverse effects on sperm DNA integrity also interfere with early embryonic development. Morris et al. showed that sperm DNA damage was strongly associated with men of age 29-44 years as well as with impairment of post-fertilization embryo cleavage [106]. In another study of 132 ICSI patients with father's age of $>40$ years, sperm DNA fragmentation was significantly affected post-implantation during embryonic development [107]. In a cross-sectional study of 215 infertile men who underwent ART, Simon et al. showed that increased sperm DNA damage negatively affected early embryonic development and significantly reduced subsequent implantation [108]. In study comprising of 1023 infertile couples, Frattarelli et al. was able to show that sperm from men $>50$ years led to normal embryonic early cleavage but showed a decrease in blastocyst formation rate [109].

Two large studies have shown that paternal aging is associated with increased risk of pregnancy loss after an established pregnancy by IUI suggesting that advanced paternal age may affect genomic integrity and thereby negatively impact the embryo development $[60,110]$. A lack of consistent significant association between paternal age and sperm concentration as well as lack of association between paternal age and IVF or ICSI pregnancy rates [60,110-113].

Contrary to this another meta-analysis report consisting of 7 IVF and IVF/ICSI studies reported no association of paternal age with pregnancy loss after an established pregnancy [113]. This could possibly be due to the fact that the natural and IUI pregnancy in these studies were from men with relatively homogenous and normal semen parameters whereas those in IVF/ ICSI were from a heterogeneous population of men and this may have diluted the effect of age.
In conclusion, advanced paternal age increases the DNA fragmentation in sperm negatively affecting the IVF/ICSI success rates, ART outcomes as well as early embryo development. Despite increasing evidence of positive correlation between sperm DNA fragmentation and reduced male infertility, the ASRM guidelines does not support the routine use of sperm DNA integrity assessment in clinical practice [100]. However, they recommend further confirmation of sperm DNA integrity test using randomized studies and a high number of patients.

\section{Telomere length}

Telomeres are tandemly repeated hexameric nucleotide repeat sequences (TTAGGG). Telomeres cap the ends of eukaryotic chromosomes. Their primary role is to preserve genomic structure and maintain its stability [114]. With each successive cell division, and hence with aging, the telomere length in somatic cells undergoes progressive shortening [115-119]. The somatic cells, for years were represented by leukocytes, but in a recent study conducted by Daniali et al. [120] four different somatic cells (leukocyte, muscle, skin and fat cells) were used to measure the association between telomere length and increasing age [120]. Like leukocytes, three other somatic cells' telomere length was also found to decrease with increasing age [120]. In somatic cells, the guanine rich repetitive telomere DNA is maintained by telomerase, a reverse transcriptase enzyme [121]. With each cell division, some telomere repeats are not copied and hence are lost. But telomerase extends telomere by adding TTAGGG repeats. With increasing age, the incomplete DNA replication leads to telomere shortening [121]. When telomere length reaches a critical length, the cell cannot divide and the cell enters cell-cycle arrest or undergoes apoptosis. Telomere length is maintained by telomerase that is maximally expressed in highly proliferative cells such as germ cells and neoplastic cells $[122,123]$. A strong positive correlation has been reported between paternal age at birth and offspring LTL [124-129].

It has been reported that increased Leukocyte Telomere Length (LTL) is associated with reduced risk of atherosclerosis and hence, increased survival. Since increased paternal age increases LTL, it is a possibility that offspring of relatively old fathers have reduced risk of atherosclerosis and increased survival [130]. Consequently, increased LTL can also increase the risk of breast cancer in daughters of old fathers since it has been reported that there is a correlation between increased LTL and increased breast cancer risk [128].

Interestingly and compared to somatic cells, sperm (germ cell) telomere length was found to increase with increasing age $[127,131,132]$. Although such rare 
mechanism of telomeres' extension remains unclear and poorly understood, it might be explained as kind of a biological resistance against the aging process. This molecular resistance expressed by human species against aging might be necessary to boost the chances of perpetuation of the species'. Further studies are required to confirm this discrepancy of telomerase extension observed in testis. In fact, it has been reported that average telomere length is heritable and can be passed down to offspring [126]. Interestingly, the effects of paternal age on telomere lengths have also been noticed in offspring [133]. It has been shown that telomere length inheritance is mainly determined by an offspring's father [134]. A meta-analysis comprising 19,000 participants was conducted by Broer et al. [7]. These investigators analyzed six studies where they randomly examined telomere length and its heritability. A negative association was reported between telomere length and the age [7]. A significant correlation was also seen between advanced male age and telomere length, though maternal age played a more significant role [7].

In offspring both sperm [133] and leukocyte telomere length increases with increasing paternal age $[129,130,133]$. The role of sperm telomeres and telomere length is still unclear. Although both leukocyte telomere length (LTL) and sperm telomere length (STL) correlate within the same individual, LTL decreases whereas STL increases with age $[127,131,132,135]$. This is more likely related to the increased activity of reverse transcriptase activity - the catalytic unit of telomerase [136,137]. High reverse transcriptase activity in germ cells or cellular attrition resulting in death of stem cells with shortened telomere length results in selection of sperm with longer telomeres [127,133].

The role of STL in spermatogenesis or fertility potential is unclear. A recent report examined a group of healthy 18-19 years old subjects and compared telomere length and sperm, spermatogenic activity and the age of the parents at birth [132]. They showed a positive correlation between STL and sperm count and significantly shorter STL in men with oligozoospermia when compared to those with normozoospermia. They also showed effect of parental age on offspring STL [132]. In another study, STL in men with idiopathic infertility and controls was examined and a shorter telomere length was reported in men with unexplained male infertility [138]. Although there were differences in these two studies mainly, in the study by Thilagavathi et al., LTL was not considered and included low number of subjects with unknown age and normal mean sperm count, sample size was small compared to the study by Ferlin et al. It is clear that telomeres play an important role in meiosis and thereby maintain genomic integrity [139]; shorter telomere suggested impaired spermatogenesis through segregation errors as telomerase activity peaks in the testis in meiosis I primary spermatocytes [139]. Shorter telomeres can be regarded as putative cause of impaired spermatogenesis and male infertility, although additional studies are needed to verify this interpretation. Shorter telomeres in ejaculated sperm may be a marker of damaged spermatogenesis and a consequence rather than a cause of altered spermatogenesis. Shorter telomere length in oligozoospermic men as reported by Thilagavathi et al. has implications in assisted reproductive techniques as the offspring will inherit smaller [138]. However additional studies are need to verify the pathophysiological link between STL and damaged spermatogenesis as well as its effect on the offspring telomere length especially in older couples where the man is oligozoospermic.

\section{DNA mutations}

In contrast to oogenesis, sperms divide (or spermatogenesis occurs) continuously throughout reproductive lifetime and hence accumulates greater number of cell divisions. Spermatozoa a can also acquire de novo single nucleotide variants or mutations because of the continuous ongoing process of spermatogenesis that involves multiple asymmetric pre-meiotic spermatogonial divisions and the testicular environment is more prone to toxic effects of oxidative stress in ageing men [8]. Furthermore errors on post-meiotic remodeling of chromatin remodeling and DNA repair cam also result in de novo mutations [140]. Spermatozoa from aging fathers can also be more prone to chromosomal aneuploidy [141]. The paternal contribution to offspring novo mutations was estimated to increase by $4 \%$ per year [142]. At the age of 20 , a sperm would have undergone 150 chromosomal replications, and at the age of 50, it would have gone through 840 replications $[8,143,144]$. This increases the probability of replication errors in the germ line leading to the accumulation of mutations and hence increased de novo mutation rate in spermatozoa [142]. This problem is further aggravated when age-sensitive processes such as DNA replication and repair are compromised due to an increasing age [8]. Kong et al. and his team reported the positive association between the age and de novo mutation rate [142]. On average, the rate of de novo mutation increases by two base pairs every successive year [142]. Kong et al. also reported that the heritability of mutations in an offspring is mainly attributed to paternal age [142]. This increases the probability of older fathers conceiving fetuses with rare and harmful disorders [145]. Paternal Age Effect (PAE) disorders are a small number of rare disorders which occurs due to specific mutations in fibroblastic growth factor receptor (FGFR) [146-148]. Wyrobek et al. found that sperm of men with age of 22-80 years associated with mutation in FGFR3 in particular and this was also associated with achondroplasia 
[149]. An increasing paternal age is one of the major sources of mutations found in human species [8]. Though this phenomenon aids in the diversification of the species, unfortunately, it can also increase the incidence of rare disorders in the human population.

A chromosomal anomaly such as Klinefelter syndrome, 47 , XXY is carried by $5 \%$ of all infertile men and microdeletions of the long arm of the Y chromosome are present in $10 \%$ of azoospermic or severely oligozoospermic men [150]. It has been shown that the post-meiotic events during spermiogenesis are critical from which de novo genetic mutation could be induced [140]. A number of mechanisms have been suggested to explain the induction of these de novo mutations. Among these is a base substitution due to the nucleotides are not incorporated by the polymerase [151], and insertion or deletion which could lead to a high rate of cell divisions and subsequent de novo mutation [152]. It is interesting to mention that the frequency and the increase in a de novo chromatin translocation detected in 10 sperm donors was found to be not an age dependant [153] suggesting a replicateindependent mechanism for formation of the translocations. NRA51 nuclear receptor also called the steroidogenic factor 1 is a key transcriptional regulator of genes. Mutations of NRE5-1 have been reported in 46,XY disorders of sex development and in $46, \mathrm{XX}$ primary ovarian insufficiency in $4 \%$ of men with otherwise unexplained severe spermatogenic failure [154]. Some forms of male factor may be an indicator of testicular dysgenesis which requires careful clinical investigation of men presenting with infertility and inconsistent testosterone and gonadotropin levels. De novo point mutation in the Y-chromosomal gene USP9Y has been reported in a man with non-obstructive azoospermia, causing spermatogenic failure [155]. Similarly these authors also reported a single-gene deletion that was associated with spermatogenic failure.

\section{Chromosomal aneuploidies}

Chromosomal aneuploidy is the presence of an abnormal number of chromosomes in a cell. Chromosomal aneuploidy is caused in a sperm when it undergoes meiosis but the chromosomes are not equally divided in daughter cells because of disjunction. Most of the aneuploid embryos die in-utero and hence chromosomal aneuploidy is the leading cause of failed pregnancy [156]. However, 1\% of aneuploid pregnancies lead to live birth [156] which accounts for a large number of congenital birth defects and/ or mental retardation [157].

On average, $10 \%$ of sperm cells of healthy male population have chromosomal aneuploidies and include chromosome 21 and 22 [158]. However, this number increases with paternal age [159]. The incidence of sex chromosome disomy 18 significantly increases among older men ( $>50$ years) when compared to younger men [159]. McIntosh et al. reported increased risk of up to two fold among fathers of 50 years and older when compared to the fathers of age group 25-29 years [160]. Table 3 summarizes the effect of paternal age on chromosomal aneuploidies.

\section{Molecular aging and genomic instability}

Aging is a multifactorial and complex process leading to progressive impaired cellular functions and hence increased vulnerability to diseases [169]. Aging affects several processes including DNA damage [170], telomere shortening [171,172] leading to cellular senescence or apoptosis [172] (Figure 1). In this context, advanced paternal age would lead to the accumulation of de novo mutations, male infertility and increased genetic risks on the offspring e.g. autism and schizophrenia [142,173]. The dysfunctional telomerase was reported to induce DNA-damage response in senescence phase [174].

Genomic instability at the cellular level will lead to variation at the gene expression level and affect microRNA (miRNA) patterns with aging $[172,175,176]$. miRNAs are non-coding RNAs consisting of small RNAs ( $\sim 22$ nucleotides) and are critical regulators of posttranscriptional gene expression by targeting mRNAs for cleavage or translational repression. These miRNAs have been identified in the seminal plasma as potential markers of male infertility and their expression patterns change with age or other stress factors as vasectomy $[177,178]$. Therefore, more work is needed at this level to enhance our comprehension of the gene players controlling normal versus abnormal sperm development, differentiation and maturation in both adult and aged cases. The final differentiation and maturation of spermatozoa occur in the epididymis where the coiled mass of tubes play crucial role in carrying, storage and maturation of sperm $[179,180]$. Zhang et al. carried out comparative expression pattern analysis of microRNAs in epididymis of newborn, adults (aged 25 years) and aged (aged 75 years). The analysis revealed that a total number of 251 miRNAs expressed in newborn epididymis (represents 63\% of the

Table 3 Effects of paternal age on some of the chromosomal aneuploidies

\begin{tabular}{lll}
\hline Type of chromosomal aneuploidy & Relative risk & Reference \\
\hline Trisomy 21 & $\uparrow$ & {$[160]$} \\
Trisomy 18 & Mixed & {$[161-163]$} \\
Trisomy 13 & Mixed & {$[161]$} \\
Trisomy 16 & No affect & {$[164]$} \\
Trisomy 15 & No affect & {$[165,166]$} \\
47,XXY & Mixed & {$[167]$} \\
45, X & Mixed & {$[168]$} \\
\hline
\end{tabular}




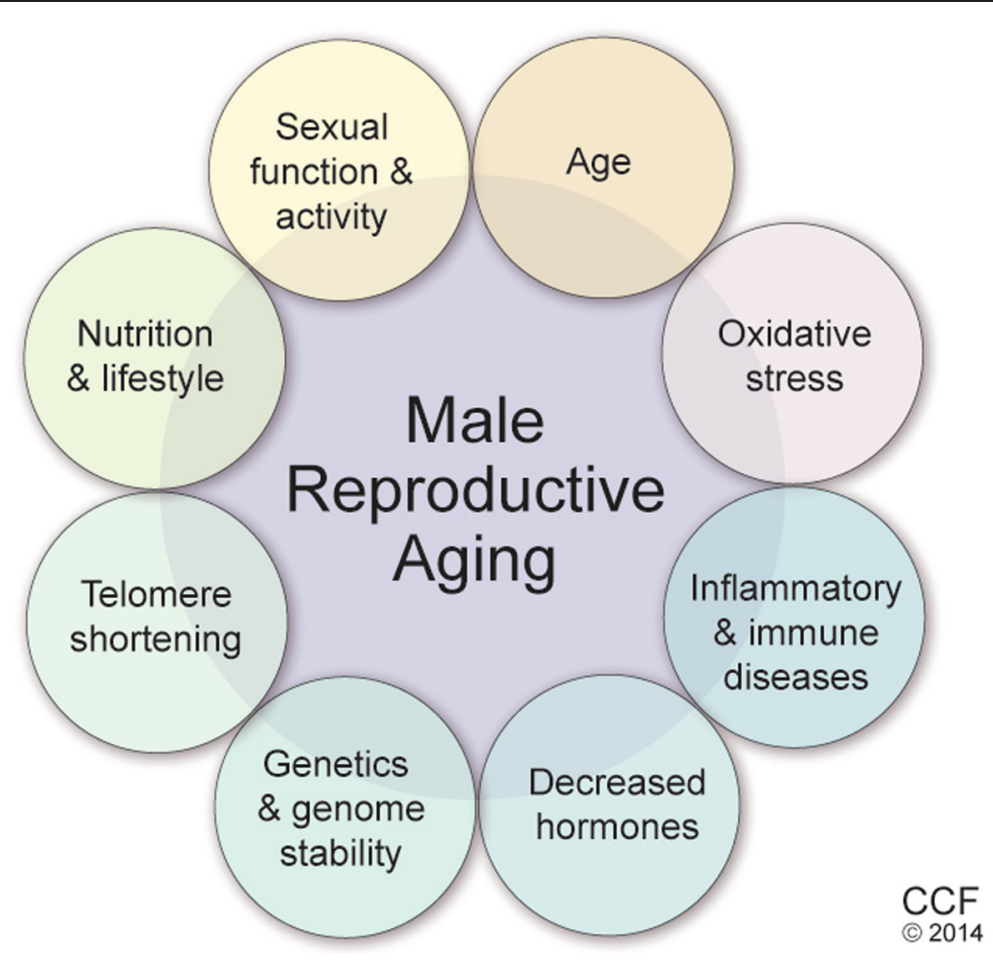

Figure 1 Main factors involved in impaired male infertility due to reproductive aging.

known miRNAs) was dropped to $31 \%$ in the aged case [181]. The mechanism through which this change in miRNAs expression affects the sperm quality and DNA integrity is to be yet investigated.

\section{Epigenetics of male aging}

Epigenetics is stable heritable modification on histone tails but not the DNA sequence that leads to altered gene expression [182]. Unlike DNA mutations, epigenetic patterns can be disrupted or silenced by various environmental and endogenous factors such as nutrition, age, drug/toxin exposure and phenotypic variation. Therefore, both spermatogenesis and spermiogenesis processes are marked by successive steps of epigenetic reprogramming of the male gamete which is influenced by several environmental factors (Figure 1). These epigenetic events may impair or inhibit key steps of fertilization, implantation and/or the embryo development [183]. Loss of methylation at the paternally imprinted H19-DMR (differentially methylated region) locus was reported in sperm of men with unexplained low sperm counts [184]. On further investigation revealed abnormalities in $14 \%$ to $20 \%$ of men with moderate or severe oligozoospermia [185-188]. Genome wide analysis suggested global hyper methylation of DNA from poor quality sperm, pointing to the poor improper erasure of DNA methylation during germ cell development [189]. Epigenetic modifications in the sperm selected for ART can also lead to perturbations or increase the imprinted congenital phenotype because of the ART technique itself. Methylation profile of two imprinted loci H19-DMR and PEG 1/MEST-DMR have been studied in men showing phenotypes ranging from severe oligozoospermia to normospermia. The methylation profile of these two loci was used as a marker of sperm DNA methylation status by Montjean et al. [190]. They found epimethylation and epimutations in 20\% in H19-DMR and 3\% in PEG 1/ MEST-DMR of spermatozoa of oligozoospermic men but did not observe an association with the genetic variants or in the ART outcome.

It has been reported that in addition to the age, the role of father's nutrition and his exposure to toxicants is so strong that not only affects his offspring's epigenetic factors but also his grand-offspring epigenetics factors as well [10]. However, a study conducted by Benchaib et al. reported that there is no correlation between DNA methylation and paternal age [191,192]. This study proves that some of the epigenetic factors are not only heritable but also stable.

DNA methylation and repressive histone modification are two of the most common mechanisms which cause gene silencing. It has been found that DNA methylation plays an important role in mammalian development and influences different processes like X-inactivation [193], genomic imprinting and embryo development as soon as the zygote is formed [194]. 
To further prove the importance of DNA methylation in embryo development, Benchaib et al. [192] conducted a prospective study to assess the influence of global sperm DNA methylation on IVF outcomes. They demonstrated that pregnancy outcomes were significantly improved in sperm with global methylation level (GML) higher than arbitrary threshold value (555 AU). However, others reported no change in fertilization rates and quality of embryos [191,192]. These investigators suggested that germ line which has been epigenetically reprogrammed might lead to compromised spermatogenesis and eventually result in infertility. Ace-1(Ace-variant1), Prm1 (Protamine 1), Prm2 (Protamine 2) and Smcp (Sperm mitochondrial-associated cysteine-rich protein) are key sperm genes which are known to bind to chromatin. A recent longitudinal study conducted on mice reported that expression levels of Ace-1, Prm1, Prm2 and Smcp genes which are genetically regulated by epigenetic factors were shown to decrease with increasing paternal age. During spermiogenesis, these proteins replace most of the canonical histones [194]. Decreased expression levels of Prm1 Prm2, Smcp result in decreased semen quality and IVF pregnancy rates [195].

Furthermore, the levels of 5-mc and 5-hmc (methylated forms of cytosine) increased (by $1.76 \%$ every year) with a concomitant increase in paternal age in donors which in turn causes gene silencing [196]. Angelman Syndrome is a neurogenetic disorder associated with both developmental and intellectual disability [197] while Bechwith-Wiedmann Syndome is a genetic disorder which is usually associated with overgrowth and increased risk of childhood cancer [198]. Gosden et al. reported that incidence of rare disorders like Angelman syndrome and Beckwith-Wiedemann syndrome increased significantly in babies conceived with different assistive reproductive techniques, suggesting that the result is possibly because relatively old couples opt for assisted reproductive technology (ART) techniques for conception [199].

\section{Paternal Age Effect (PAE) disorders}

The correlation between increasing paternal age and genetic defects was first suggested in late 1800 s by Weinburg [200] while the association between increasing paternal age and genetic disorder such as Achondroplasia was found by Penrose in 1955 [201]. Ever since, many other genetic disorders have been associated to increasing paternal age. An increase in de novo mutation rate has been reported as the major cause of paternal age effect disorders (Figure 1). Most of the mutations detected in disorders associated with increasing paternal age are single base pair substitutions [202]. In a study conducted by Kong et al. using deep sequencing analysis, they reported that with increasing paternal age, the germ line single base pair substitutions increased at the rate of 2 base pairs per year [142]. Realizing the significance of paternal age disorders in male, the British Andrology Society and American Society for Reproductive Medicine set the upper age limit for sperm donors at 40 years [203,204].

In this section we will highlight some of the genetic disorders which are associated with advancing paternal age.

\section{Schizophrenia}

Advanced paternal age has been associated with schizophrenia in many studies [14,205-208]. Schizophrenia is a psychiatric disorder which is associated with disabilities in social and occupational functioning. It also involves recurrent or chronic psychosis [209]. Schizophrenia is not only lethal in terms of the disability caused to a victim, but also an economically burdening disorder. It has been ranked by WHO as one of the top ten diseases contributing to global burden of diseases [210]. Schizophrenia is an etiologically heterogeneous syndrome and has a strong genetic influence [211,212]. The genetic influence is so strong that a quarter of all cases of schizophrenia are attributed to increasing paternal age [213].

In a cohort study comprising of 754,330 Swedish subjects, it was reported that with every 10 year increase in paternal age at the time of conception, the risk of an offspring having schizophrenia increased by 1.47 times. Interestingly, offspring with younger fathers $(<21$ years) were also at a higher risk of schizophrenia compared to the fathers aged 21-24years at the time of conception [206]. In a meta-analysis conducted by Miller et al. comprising of 12 cohort and case-control studies, the offsprings of older fathers ( $>30$ years) had higher risks of schizophrenia compared to reference paternal age of 25-29 years. Similar to the result of Swedish cohort study mentioned earlier, Miller et al. also showed that younger fathers ( $<25$ years old) had higher risk (Relative Risk ratio $=1.08,95 \% \mathrm{CI}$ : $1.02-1.14, \mathrm{P}=0.01)$ compared to the age group of 25-29 years old fathers [207].

To further investigate whether socially and culturally different countries showed similar association between advanced paternal age and schizophrenia, Tsuchiya et al. and his team conducted a study in Japan and reported a similar association [214]. Wohl et al. conducted a study to compare the effect of different paternal age groups on risk factor of schizophrenia in offsprings. The odds ratio for fathers' age increased exponentially from 1.16 in age group 25-34 years to 5.92 in fathers over the age of 55 years [215].

Frans et al. conducted a national register-based cohort study which involved 120,758 individuals to examine whether grandparent's age contributed to the grand offspring's risk of having schizophrenia. It was observed that old grandmother's age increased the risk of schizophrenia in grandchild but not grandfather's age [208]. 
It has been reported that the association between paternal age and schizophrenia is mainly due to the accumulation of de novo mutations in sperm [206,208,211,212]. Although a number of studies have supported the mechanism of de novo mutations as a causative factor for the occurrence of Schizophrenia, other mechanisms may play a role. For example, when the age of a father was adjusted for first fatherhood, no association was found between increased paternal age and increased risk [216].

Dysregulation of epigenetics at the DNA methylation, histone modifications or chromatin remodelling level, with respect to increasing paternal age could also increase the risk of Schizophrenia. Genomic imprinting also known as parental imprinting is a phenomenon in which a gene is expressed in a parent of origin-specific manner [217]. Alterations in epigenetic mechanisms like parental imprinting can also have negative implications on the offspring [218].

\section{Bipolar disorder}

Bipolar Disorder (BPD) is a heterogeneous brain disorder associated with severe mood swings. Many studies have shown significant association between risk factors of BPD in offspring's with increased paternal age [14,219,220].

A population based registry study involving 7, 328, and 100 individuals conducted by Frans et al. found out that the risk for BPD in offsprings increased with increased paternal age [219]. In comparison to offsprings of fathers aged 20-24 (control group), the offsprings of fathers aged 55 and older had 1.34 times higher risk of being diagnosed with BPD [219]. Offspring's whose fathers were $<20$ years old at the time of their birth had 2.63 times higher risk of being diagnosed with BPD [219]. The reasons behind increased risk of BPD in younger population can be due to immature sperm, stressful environment, smoking and even alcohol abuse. Also, younger fathers are likely to come from disadvantaged background, which can contribute to poor postnatal care [209]. Menezes et al. showed that with increase of every ten years in paternal age, the risk factor for BPD in offspring increased by 1.20 times after adjusting for maternal age [220].

In a recent population-based cohort study which involved $2,615,081$ individuals from Sweden, it was reported that increased paternal age was associated with increased risk of bipolar disorder. The offsprings born to parents $>45$ years old had increased hazard ratio (or relative risk ratio) of 24.7 compared to off springs born to parents 20-24 years old [14]. In contrast, Buizer-Voskamp et al. did not find any association between advanced paternal age and increased risk factor of BPD [205].

Similar to schizophrenia and other mental disorders associated with increasing paternal age, BPD might possibly result from de novo mutations which are caused by DNA copy errors. Epigenetics might also play role in causing paternal age effect disorders, [209,221]. Kaminsky et al. [222] reported that compared to the control group, the DNA methylation of human leukocyte antigen [223] complex group 9 gene (HCG9) increased in BPD patients. This might explain the possible mechanism of the occurrence of increased risk factor for BPD for offsprings with advanced paternal age since, DNA methylation increases with advanced paternal age.

\section{Autism}

Autism spectrum disorder refers to a group of complex disorders which are characterized by difficulties in verbal and nonverbal communications, interaction with people and tendency to display repetitive behaviours [224]. Autism is usually diagnosed in children at an early age of 3 years [225].

Many studies have shown that there is a significant association between increased paternal age and the risk of autism [14,205,226-229]. In a recent registry study conducted by Buizer-Voskamp and his group, it was calculated that in comparison to younger fathers $(<20 \mathrm{y})$, older fathers $(>45 \mathrm{y})$ had 3.3 times higher risk of conceiving an offspring with autism [205]. Similarly, Reichenberg et al. [226] reported that compared to offspring's of parents who were $<30$ years old, the offspring's of parents $>50$ years had 5.75 higher risk of having autism. Another study performed on Icelandic population concluded a statistically significant correlation between increasing paternal age and autism [142]. In a meta-analysis conducted by Hultman et al. it was found that the risk of autism in offspring increased with advanced paternal age [227]. Compared to reference age group $(<29 \mathrm{y})$, the risk of autism increased two fold in offsprings of age group $>50$ years, while controlling maternal age and other risk factors [227].

Interestingly, a significant association was also found between advanced grandpaternal age at the time a parent was born and the risk of autism in grandchildren. An offspring would have 1.79 times increased chance of having autism if his/her maternal grandfather gave birth to his/her mother when he was over the age of 50 years. For an offspring with paternal grandfather, the risk is reduced to 1.67 times but it is still significantly higher [182,230]. Using an animal model, a similar association was found in mouse which displayed decreased sociability, increased grooming activity, increased ultrasound vocalization (USV) activity and increased anxiety-like responses in offsprings of grandfather who gave birth to their parents at an older age [231].

It is believed that one of the causative factors of autism is mutation of transcription factors which play dominant role in gene expression [224]. As discussed earlier, epigenetic factors have a very high heritability and this might explain the reason why higher risk of autism is found across the generations. Some studies have 
also proposed that age-related de-novo mutations in male germ contribute to increased risk of neurodevelopmental disorders like autism [232,233].

\section{Other disorders}

We have discussed the effect of paternal age on different neurocognitive disorders. Other specific conditions ranging from autosomal disorders such as Achondroplasia and Apert Syndrome to various congenital anomalies like Klinefelter syndrome have been associated with increasing paternal age. Some of the most common disorders associated with advanced paternal age are shown in Table 4.

\section{Reproductive and fertility outcomes \\ Advanced paternal age and time to pregnancy/male fecundity}

Fecundity is defined as the likelihood of achieving a pregnancy in a defined period of time. Using time to conception as an index to measure male fecundity, Ford et al. [250] reported that there is a significant decline in male fecundity with advanced paternal age after adjusting maternal age and other confounding factors. For men older than 40 years, the odds ratios for conception in $<12$ months were 0.62 for $30-34$ years old, 0.50 for 35-39 years old and 0.51 compared to the reference age group $(<25$ y) [250]. However, one of the limitations of this study was that it was unable to determine whether the male fecundity reduced solely because of the biological changes in male reproductive system or because of reduced coital frequency, which is also associated with increasing paternal age [21-24]. Association of paternal age with fertility is contradictory. This may be attributed to the decline in male sexual activity as frequency of intercourse decreases with age. The general consensus is that paternal age is associated with reduced fertility especially in couples where men are older than 40 years and age of the women is at least 35 years $[251,252]$. To find the effect of biological changes in failure to conceive, de La Rochebrochard et al. [204] conducted a study to find the association between advanced paternal age and the risk of failure to conceive after IVF attempts. They reported that the odds ratio of 1.70 for paternal age of 40 years and older compared to 30 years and younger, showing significant increase in failure to conceive [204]. When maternal age was involved, the odds ratio increased to 2.00 for men $>40$ years when the woman was 35-37 years and the odds ratio increased exponentially for same paternal age when the maternal age increased to $>41$ years [204].

In a similar study conducted by Hassan et al. it was reported that compared to men who were $<25$ years, older men who were $>45$ years had 4.5 times and 12.5 times increasing risk of having Time to Pregnancy (TTP) of $>1$ years and $>2$ years respectively [253]. Dunson et al. also reported significantly reduced fertility in men $>35$ years [254].

\section{Paternal age, intrauterine insemination success and live birth rates}

Reports have shown a decrease in assisted pregnancy rate with increasing paternal age, [255-257]. Mathieu et al. reported that male age $\geq 35 \mathrm{y}$ was associated with decreased clinical pregnancy rate [255]. Belloc et al. reported that significant decline in artificial conception rate when pregnancy rate decreased from $12.3 \%$ per cycle in men aged $<30$ to $9.3 \%$ in men $\geq 45$ years Belloc et al. [256]. Similar findings were reported by Demir et al. [257]. In a prospective study conducted by Klonoff-Cohen et al. it was reported that with increasing paternal age, the live birth rate decreased, showing a decrease in artificial pregnancy rate [258].

\section{Spontaneous abortions}

Spontaneous abortion is defined as loss of pregnancy occurring before 20 weeks of gestation [158]. It is seen in $10-15 \%$ of clinically recognized pregnancies [259]. Increasing paternal age is significantly associated with the risk of spontaneous abortions [260]. In a retrospective study, de la Rochebrochard and her colleagues [260] reported that compared with 20-29 years age group (both paternal and maternal), the odds ratio of risk of having miscarriage increased to 1.06, 1.31 and 1.80 when the paternal age increased from 30-34 years, 35-39 years and 40-64 respectively while the maternal age remained unchanged at 20-29 years. Similarly in another study, the odds ratio increased by $1.2,1.5$ and 1.3 for age groups 30-34y, 35-39y and >40 years old respectively, after adjusting for maternal age [261]. Slama et al. reported that subjects in $>35$ years group had increased risk of 1.27 times compared to $<35$ years age group [262]. In a recent French study, Belloc et al. reported an increase in miscarriage rate to $32.4 \%$ in fathers $\geq 45$ years compared to $13.7 \%$ in the fathers who were $<30$ years [256]. However, not all studies showed similar results $[113,258,263,264]$.

\section{Pre-eclampsia and advanced paternal age}

Pre-eclampsia refers to the onset of hypertension and either proteinuria or end-organ dysfunction after 20 weeks of gestation in a previously normotensive woman [265]. Harlap et al. reported a significant association between increasing paternal age and preeclampsia [266]. These authors observed an increase in the odds ratio in $35-39 y, 45-49 y$ and $50-54 y$ paternal age groups by $1.30,1.89$ and 1.54 respectively, compared to the $25-29 y$ paternal age group and this was independent of maternal age [266,267]. 
Table 4 Effect of paternal age on various disorders showing effect of age and relative risk ratio

\begin{tabular}{|c|c|c|c|c|}
\hline Type of disorder & Disorder & Age (Reference age) & Relative risk & Reference \\
\hline \multirow[t]{7}{*}{ Neuro-cognitive } & Autism & $>45(<20)$ & 3.3 & {$[205]$} \\
\hline & & $>50(<30)$ & 5.75 & {$[226]$} \\
\hline & & $>50(<29)$ & 2.2 & {$[142,227]$} \\
\hline & Bipolar disorder & $>55(20-24)$ & 1.34 & [219] \\
\hline & & Not specified & 1.20 & {$[220]$} \\
\hline & & $>45(20-24)$ & 24.7 (Hazard Ratio) & {$[14,206]$} \\
\hline & Schizophrenia & Not specified & 1.47 & {$[207]$} \\
\hline \multirow[t]{13}{*}{ Autosomal dominant } & & $>50(25-29)$ & 1.66 & {$[214,215]$} \\
\hline & & $>32(<28)$ & 3.00 & [13] \\
\hline & & $>55(25)$ & 5.92 & {$[211,213,216]$} \\
\hline & Achondroplasia & $>30(<30)$ & 3.48 & [234] \\
\hline & & $>50(25-29)$ & 7.80 & {$[236]$} \\
\hline & Apert syndrome & - & - & {$[235-237]$} \\
\hline & Neurofibromatosis I & $>35(<35)$ & 1.69 & [238] \\
\hline & & $>40(<30)$ & 2.9 & [239] \\
\hline & Osteogenesis imperfecta & $22-80$ & 1.37 & [13] \\
\hline & & $>35(<35)$ & 1.62 & {$[240]$} \\
\hline & & $>35(<25)$ & - & - \\
\hline & Retinoblastoma & $>35($ Not specified) & 1.73 & [241] \\
\hline & & $>45$ & 3.00 & {$[242]$} \\
\hline \multirow[t]{21}{*}{ Congenital Abnormalities } & Cleft Lips & Not specified & & {$[243]$} \\
\hline & Anencephaly & $>40$ & & {$[11]$} \\
\hline & Transposition of Great Vessels & $>45>40$ & 1.27 & [11] \\
\hline & & & 1.20 & \\
\hline & Ventricular Septal Defects & $>35$ & 3.63 & {$[160]$} \\
\hline & & $30-34$ & 1.69 & \\
\hline & & $(25-29)$ & & \\
\hline & Artrial Septal Defect & $35-39$ & 1.95 & {$[160]$} \\
\hline & & $(25-29)$ & 1.2 & \\
\hline & & $40-44$ & & \\
\hline & & $(25-29)$ & & \\
\hline & Neural tube defect & $45-49$ & 1.3 & {$[160]$} \\
\hline & & $(25-29)$ & & \\
\hline & & $>50(25-29)$ & 1.6 & [160] \\
\hline & & $35-39$ & 0.6 & {$[244-246]$} \\
\hline & & $(20-29)$ & & \\
\hline & & $>50(25-29$ & 2.3 & {$[244-246]$} \\
\hline & MSA & $>35(30-34)$ & 1.33 & {$[246]$} \\
\hline & Tracheoesophageal fistula & $30-34(<25)$ & 2.55 & [247] \\
\hline & & - & 3.12 & {$[248]$} \\
\hline & & - & 1.34 & {$[248]$} \\
\hline \multirow[t]{3}{*}{ Others } & OCD & $>40$ & 1.14 & {$[248]$} \\
\hline & Childhood CNS Tumor & $>35-39$ & 1.11 & {$[248]$} \\
\hline & & $(25-29)$ & & \\
\hline
\end{tabular}


Table 4 Effect of paternal age on various disorders showing effect of age and relative risk ratio (Continued)

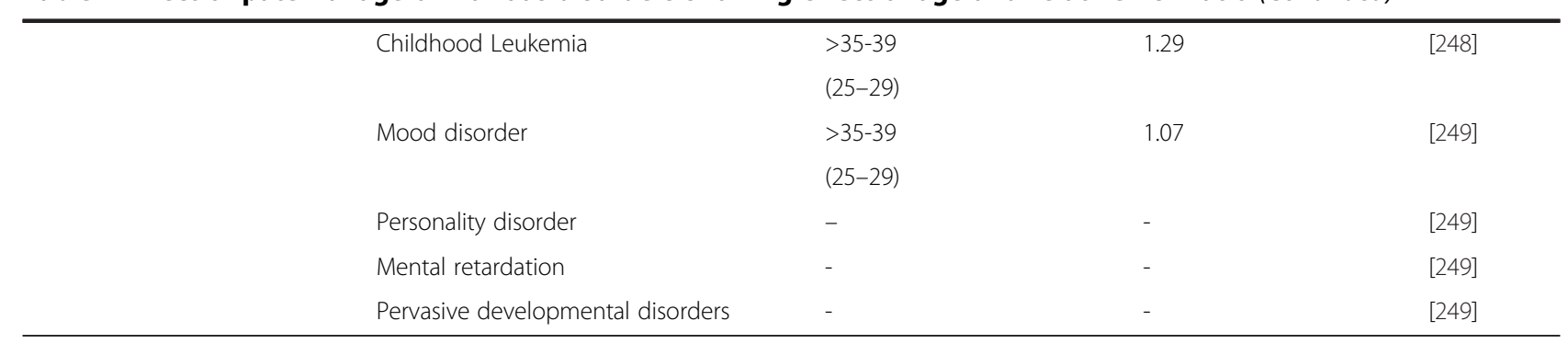

\section{Pre-term birth and low birth weight and increasing paternal age}

Pre-term delivery is defined by the occurrence of delivery before the completion of 37 weeks of gestation [268]. Preterm birth is responsible for causing $27 \%$ neonatal deaths worldwide, leading to over a million deaths annually [269]. It is also associated with more than $70 \%$ of early life morbidity and mortality, making it one of the largest health problems in reproductive health [270]. Zhu et al. reported that with increasing paternal age, the risk of preterm births increased [271]. Compared with the reference age group 20-24 years, paternal age groups 25-29y, 35-39y, $40-44 y, 45-49 y$ and $>50 y$ showed increased odds ratio of $1.3,1.4,1.7,1.6$ and 2.1 respectively for pre-term birth [271]. Astolfi et al. reported that the odds ratio for preterm increased with increasing paternal age. They reported that father's age group had increased odds ratio of 1.91 and 1.71 when adjusted for maternal age of 20-24 and 25-29 respectively [272]. However, some of the previously conducted studies did not find any significant association between paternal age and increased risk of pre-term, [273-276].

Low birth weight is a leading cause of infant mortality in the United States. It is associated with attention deficit hyperactivity disorder (ADHD), blindness, epilepsy, chronic lung disease, cerebral palsy, all of them leading to long term health problems [277]. Alio et al. reported that in comparison to the paternal age group of 25-29 years, age group $>45$ years had $19 \%$ increased likelihood of low birth weight and $13 \%$ increased risk of preterm (between 33 and 37 weeks of gestation) birth [12]. In another study, Reichman et al. conducted a cohort study in which they concluded that fathers aged $\geq 35 \mathrm{y}$ had 1.9 times increased risk of conceiving low-birth weight offspring compared to 20-34y group [9].

\section{Still-birth/ fetal death and increasing paternal age}

Still-birth defines a fetal death that occurs prior to the expulsion from its mother [278]. Alio et al. conducted a study where the paternal age group $>45$ years had $48 \%$ increased risk of still-birth (utero-fetal death $\geq 28$ weeks) compared to the 25-29 years group [12]. In a cohort study conducted by Nybo et al. it was found out that the pregnancies fathered by men aged 45-49 y had an increased risk of late fetal death ( $>20$ weeks of gestation) with an odds ratio of 1.40 when adjusted for maternal age [279].

For pregnancies fathered by men aged $\geq 50$ years, both the risks for early fetal death ( $\leq 20$ weeks of gestation) and late fetal death increased with the hazard ratio of 1.38 and 3.94 respectively [279]. Alio et al. reported that in comparison to the paternal age group of 25-29 years, age group $>45$ years had $22 \%$ increased risk of stillbirth [12]. Similarly, Astolfi et al. reported that father's aged $\geq 40 \mathrm{y}$ contributed to increase stillbirth risk compared to fathers in younger age groups [280].

\section{Genome-wide association studies and male reproductive aging}

The post-genomic area is marked by the development of cutting edge technologies that allowed a wide screening of the whole human genome at once. These genome-wide association studies (GWAS) have been widely used to study complex traits and to identify key genomic regions associated to several diseases. In this context, more than 1000 male infertility-associated genes have been already reported [281]. However, the transcriptomic, genomic and epigenomic behavior of these genes as well as many single-nucleotide polymorphisms (SNP) during the male reproductive aging is still unknown. A gene discovery approach based on hybridization/ microarrays technologies and followed by specific target identification using high throughput sequencing are required to further our comprehension of the molecular mechanism and signaling pathways underlying the male reproductive function in general and specifically the aging process [282]. A suitable choice of the type of tissues/fluids, the stage, and the factors to be investigated are also key elements to be considered (Figure 1), [283-285].

The GWAS technique has the potential to unravel many genetic disorders through the analysis (sequencing) of the DNA, RNA, miRNA, SNPs, copy number variations (CNVs), insertions/deletions and other genomic parameters related to male infertility and aging, [105,145,286]. However, such studies require a proper experimental design and enough number of patients with comparable 
characteristics which is challenging given the scarcity of the samples and the various aging effects to be assessed [169]. These suggested data are required to set up functional validation [281] to demystify the role of each target genes and understand the molecular process of male infertility in its entirety, at a particular stage and over time.

\section{Conclusions and future directions}

Several studies have demonstrated the effects of increasing paternal age on various molecular mechanisms such as DNA mutations, chromosomal aberrations and epigenetic patterns. This molecular aging process was shown to induce changes in reproductive hormones' profiles, decrease sperm quality parameters and contribute to male infertility. These alterations are also responsible for various types of congenital disorders and pregnancy outcomes such as spontaneous abortions and preterm births. Although a number of studies have been conducted to assess the negative effects involved with increasing paternal age, the molecular mechanisms which cause the effects are still poorly understood. It is proposed that further research should be conducted to demystify the mechanisms involved. The use of cutting-edge technologies mainly next-generation sequencing to study the relationship between aging and male infertility will build a framework for future studies on the molecular reproductive aging in order to design advanced male infertility diagnostic and therapeutic tools to delay the aging aforementioned negative effect. The identification of aging versus longevity-related genes will also help to predict the age impact on the reproductive function. Furthermore, it will be possible to accurately establish an 'Age Threshold'which once crossed; a prospective father should attend a counselling session in which he should be educated about the risks involved with conceiving an offspring at old age.

\section{Abbreviations \\ Ace-1: Ace-variant1; ADHD: Attention deficit hyperactivity disorder; ART: Assisted reproductive technology; AU: Arbitrary units; BPD: Bipolar disorder; DFI: DNA fragmentation index; DHEA: Dehydroepiandrosterone; DHT: Dihydrotestosterone; FGFR: Fibroblastic growth factor receptor; FSH: Follicle-stimulating hormone; GML: Global methylation level; GnRH: Gonadotropin-releasing hormone; HPT: Hypothalamic-pituitary- testicular; ICSI: Intracytoplasmic sperm injection; IUI: Intrauterine insemination; IVF: In vitro fertilization; LH: Luteinizing hormone; LTL: Leukocyte telomere length; PAE: Paternal age effect; Prm1: Protamine 1; Prm2: Protamine 2; SHBG: Sex hormone-binding globulin; Smcp: Sperm mitochondrial-associated cysteine-rich protein; TTP: Time to pregnancy; USV: Ultrasound vocalization; WHO: World Health Organization.}

\section{Competing interests}

The authors declare that they have no competing interests.

\section{Authors' contributions}

RKS conceived the idea, supervised the study, and edited the article for submission. VR reviewed the literature, researched the article and wrote the article. AA, MA and AMA helped with reviewing and editing of the article. All authors read and approved the final manuscript.

\section{Acknowledgements}

The authors are grateful to Amy Moore for editorial assistance. This study was supported by funding from the Center for Reproductive Medicine, Cleveland Clinic.

\section{Author details}

${ }^{1}$ Center for Reproductive Medicine, Cleveland Clinic, Cleveland, $\mathrm{OH}$, USA. ${ }^{2}$ Center of Excellence in Genomic Medicine Research, King AbdulAziz University, Jeddah, Saudi Arabia. ${ }^{3}$ KACST Technology Innovation Center in Personalized Medicine at King AbdulAziz University, Jeddah, Saudi Arabia. ${ }^{4}$ Obstetrics and Gynecology Department, King Abdulaziz University Hospital, Jeddah, Saudi Arabia.

Received: 31 December 2014 Accepted: 9 April 2015

Published online: 19 April 2015

\section{References}

1. Bray I, Gunnell D, Davey SG. Advanced paternal age: how old is too old? J Epidemiol Community Health. 2006;60:851-3.

2. Handelsman DJ, Staraj S. Testicular size: the effects of aging, malnutrition, and illness. J Androl. 1985;6:144-51.

3. Feldman HA, Longcope C, Derby CA, Johannes CB, Araujo AB, Coviello AD, et al. Age trends in the level of serum testosterone and other hormones in middle-aged men: longitudinal results from the Massachusetts male aging study. J Clin Endocrinol Metab. 2002;87:589-98.

4. Brahem S, Mehdi M, Elghezal $H$, Saad A. The effects of male aging on semen quality, sperm DNA fragmentation and chromosomal abnormalities in an infertile population. J Assist Reprod Genet. 2011;28:425-32.

5. Agarwal A, Makker K, Sharma R. Clinical relevance of oxidative stress in male factor infertility: an update. Am J Reprod Immunol. 2008;59:2-11.

6. Moskovtsev SI, Willis J, Mullen JB. Age-related decline in sperm deoxyribonucleic acid integrity in patients evaluated for male infertility. Fertil Steril. 2006;85:496-9.

7. Broer L, Codd V, Nyholt DR, Deelen J, Mangino M, Willemsen G, et al. Meta-analysis of telomere length in 19,713 subjects reveals high heritability, stronger maternal inheritance and a paternal age effect. Eur J Hum Genet. 2013;21:1163-8.

8. Crow JF. The origins, patterns and implications of human spontaneous mutation. Nat Rev Genet. 2000;1:40-7.

9. Reichman NE, Teitler JO. Paternal age as a risk factor for low birthweight. Am J Public Health. 2006;96:862-6.

10. Curley JP, Mashoodh R, Champagne FA. Epigenetics and the origins of paternal effects. Horm Behav. 2011;59:306-14.

11. Lian ZH, Zack MM, Erickson JD. Paternal age and the occurrence of birth defects. Am J Hum Genet. 1986;39:648-60.

12. Alio AP, Salihu HM, McIntosh C, August EM, Weldeselasse H, Sanchez E, et al. The effect of paternal age on fetal birth outcomes. Am J Mens Health. 2012;6:427-35

13. Orioli IM, Castilla EE, Scarano G, Mastroiacovo P. Effect of paternal age in achondroplasia, thanatophoric dysplasia, and osteogenesis imperfecta. Am J Med Genet. 1995;59:209-17.

14. D'Onofrio BM, Rickert ME, Frans E, Kuja-Halkola R, Almqvist C, Sjolander A, et al. Paternal age at childbearing and offspring psychiatric and academic morbidity. JAMA Psychiatry. 2014;71:432-8.

15. Mahmoud AM, Goemaere S, El-Garem Y, Van Pottelbergh I, Comhaire FH, Kaufman JM. Testicular volume in relation to hormonal indices of gonadal function in community-dwelling elderly men. J Clin Endocrinol Metab. 2003:88:179-84.

16. Johnson L, Abdo JG, Petty CS, Neaves WB. Effect of age on the composition of seminiferous tubular boundary tissue and on the volume of each component in humans. Fertil Steril. 1988;49:1045-51.

17. Plas $E$, Berger $P$, Hermann $M$, Pflüger $H$. Effects of aging on male fertility? Exp Gerontol. 2000;35:543-51.

18. Sasano N, Ichijo S. Vascular patterns of the human testis with special reference to its senile changes. Tohoku J Exp Med. 1969;99:269-80.

19. Neaves WB, Johnson L, Porter JC, Parker Jr CR, Petty CS. Leydig cell numbers, daily sperm production, and serum gonadotropin levels in aging men. J Clin Endocrinol Metab. 1984;59:756-63.

20. Johnson L, Grumbles JS, Bagheri A, Petty CS. Increased germ cell degeneration during postprophase of meiosis is related to increased serum 
follicle-stimulating hormone concentrations and reduced daily sperm production in aged men. Biol Reprod. 1990;42:281-7.

21. Kaufman JM, T'Sjoen $\mathrm{G}$. The effects of testosterone deficiency on male sexual function. Aging Male. 2002;5:242-7.

22. Weinstein M, Stark M. Behavioral and biological determinants of fecundability. Ann N Y Acad Sci. 1994;18(709):128-44.

23. Mirone V, Ricci E, Gentile V, Basile Fasolo C, Parazzini F. Determinants of erectile dysfunction risk in a large series of Italian men attending andrology clinics. Eur Urol. 2004;45:87-91.

24. Handelsman DJ. Male reproductive Ageing: human fertility, androgens, and hormone dependent disease. Novartis Foundation Symp. 2002;242:66-77.

25. Mastrogiacomo I, Feghali G, Foresta C, Ruzza G. Andropause: incidence and pathogenesis. Arch Androl. 1982;9:293-6.

26. Gray A, Feldman HA, McKinlay JB, Longcope C. Age, disease, and changing sex hormone levels in middle-aged men: results of the Massachusetts Male Aging Study. J Clin Endocrinol Metab. 1991;73:1016-25.

27. Wu FC, Tajar A, Pye SR, Silman AJ, Finn JD, O'Neill TW, et al. Hypothalamic-pituitary-testicular axis disruptions in older men are differentially linked to age and modifiable risk factors: the European Male Aging Study. J Clin Endocrinol Metab. 2008;93:2737-45.

28. Orentreich N, Brind JL, Vogelman JH, Andres R, Baldwin H. Long-term longitudinal measurements of plasma dehydroepiandrosterone sulfate in normal men. J Clin Endocrinol Metab. 1992;75:1002-4.

29. Orwoll E, Lambert LC, Marshall LM, Phipps K, Blank J, Barrett-Connor E, et al. Testosterone and estradiol among older men. J Clin Endocrinol Metabol. 2006;91:1336-44

30. Scott RS, Burger HG. An inverse relationship exists between seminal plasma inhibin and serum follicle-stimulating hormone in man. J Clin Endocrinol Metab. 1981:52:796-803.

31. deKretser DM, Burger HG, Bremner WJ. Control of FSH and LH secretion. In: deKretser DM, Burger HG, Hudson B, editors. The Pituitary and Testis. Berlin: Springer; 1983. p. 12-8.

32. Gruenewald DA, Naai MA, Marck BT, Matsumoto AM. Age-related decrease in hypothalamic gonadotropin-releasing hormone (GnRH) gene expression but not pituitary responsiveness to GnRH, in the male Brown Norway rat. J Androl. 2000;21:72-84.

33. Baker HWG, Hudson B. Changes in the pituitary-testicular axis with age. In: Dekretser DM, Burger HG, Hudson B, editors. Monographs on Endocrinology. Vol. 25: The Pituitary and Testis. Clinical and Experimental Studies. New York: Springer; 1983. p. 711-84.

34. World Health Organization. WHO Laboratory Manual for Examination of Human Semen and Semen-Cervical Mucus Interaction. 4th ed. Cambridge: Cambridge University Press; 1999.

35. Agarwal A, Sekhon LH. Oxidative stress and antioxidants for idiopathic oligoasthenoteratospermia: Is it justified? Indian J Urol. 2011;27:74-85.

36. World Health Organization. WHO laboratory manual for the examination and processing of human semen. 5th ed. Geneva: World Health Organization; 2010

37. Esteves SC, Zini A, Aziz N, Alvarez JG, Sabanegh Jr ES, Agarwal A. Critical appraisal of World Health Organization's new reference values for human semen characteristics and effect on diagnosis and treatment of subfertile men. Urology. 2012;79:16-22.

38. American Urological Association. The Optimal Evaluation of the Infertile Male: AUA Best Practice Statement [revised 2010]. Available from: http://www.auanet.org/common/pdf/education/clinical-guidance/MaleInfertility-d.pdf. Accessed 4 April 2015

39. Dohle GR, Diemer T, Giwercman A, Jungwirth A, Kopa Z, Krausz C. European Association of Urology. Infertility: Guidelines on Male; 2010. Available from: http://www.uroweb.org/gls/pdf/Male\%20Infertility\%202010.pdf. Accessed 4 April 2015

40. Kidd SA, Eskenazi B, Wyrobek AJ. Effects of male age on semen quality and fertility: a review of the literature. Fertil Steril. 2001;75:237-48.

41. Hossain MM, Fatima P, Rahman D, Hossain HB. Semen parameters at different age groups of male partners of infertile couples. Mymensingh Med J. 2012:21:306-15.

42. Mukhopadhyay D, Varghese AC, Pal M, Banerjee SK, Bhattacharyya AK, Sharma RK, et al. Semen quality and age-specific changes: a study between two decades on 3,729 male partners of couples with normal sperm count and attending an andrology laboratory for infertility-related problems in an Indian city. Fertil Steril. 2010;93:2247-54.
43. Stone BA, Alex A, Werlin LB, Marrs RP. Age thresholds for changes in semen parameters in men. Fertil Steril. 2013;100:952-8.

44. Molina RI, Martini AC, Tissera A, Olmedo J, Senestrari D, de Cuneo MF, et al. Semen quality and aging: analysis of 9.168 samples in Cordoba. Argentina. Arch Esp Urol. 2010;63:214-22.

45. Jung A, Schuppe HC, Schill WB. Comparison of semen quality in older and younger men attending an andrology clinic. Andrologia. 2002;34:116-22.

46. Eskenazi B, Wyrobek AJ, Sloter E, Kidd SA, Moore L, Young S, et al. The association of age and semen quality in healthy men. Hum Reprod. 2003:18:447-54.

47. Levitas E, Lunenfeld E, Weisz N, Friger M, Potashnik G. Relationship between age and semen parameters in men with normal sperm concentration: analysis of 6022 semen samples. Andrologia. 2007;39:45-50.

48. Zhu QX, Meads C, Lu ML, Wu JQ, Zhou WJ, Gao ES. Turning point of age for semen quality: a population-based study in Chinese men. Fertil Steril. 2011;96:572-6.

49. Marcon L, Boissonneault G. Transient DNA strand breaks during mouse and human spermiogenesis new insights in stage specificity and link to chromatin remodeling. Biol Reprod. 2004;70:910-8.

50. Sloter E, Schmid TE, Marchetti F, Eskenazi B, Nath J, Wyrobek AJ. Quantitative effects of male age on sperm motion. Hum Reprod. 2006;21:2868-75

51. Guzick DS, Overstreet JW, Factor-Litvak P, Brazil CK, Nakajima ST, Coutifaris C, et al. Sperm morphology, motility, and concentration in fertile and infertile men. National Cooperative Reproductive Medicine Network. N Engl J Med. 2001;345:1388-93

52. Keel BA. Within- and between-subject variation in semen parameters in infertile men and normal semen donors. Fertil Steril. 2006;85:128-34.

53. Carrell DT, Liu L. Altered protamine 2 expression is uncommon in donors of known fertility, but common among men with poor fertilizing capacity, and may reflect other abnormalities of spermiogenesis. J Androl. 2001;22:604-10.

54. Aoki W, Moskovtsev SI, Willis J, Liu L, Mullen JB, Carrell DT. DNA integrity is compromised in protamine-deficient human sperm. J Androl. 2005;26:741-8

55. Aoki WW, Emery BR, Liu L, Carrell DT. Protamine levels vary between individual sperm cells of infertile human males and correlate with viability and DNA integrity. J Androl. 2006;27:890-8.

56. Oliva R. Protamines and male infertility. Hum Reprod Update. 2006;12:417-35.

57. Erenpreiss J, Spano M, Erenpreisa J, Bungum M, Giwercman A. Sperm chromatin structure and male fertility: biological and clinical aspects. Asian J Androl. 2006:8:11-29.

58. Zhang X, San Gabriel M, Zini A. Sperm nuclear protamine to histone ratio in fertile and infertile men: evidence of heterogeneous sub-populations of spermatozoa in the ejaculate. J Androl. 2006;27:414-20.

59. Carrell DT, Emery BR, Hammoud S. The aetiology of sperm protamine abnormalities and their potential impact on the sperm epigenome. Int J Androl. 2008;31:537-45.

60. Belloc S, Hazout A, Zini A, Merviel P, Cabry R, Chahine H, et al. How to overcome male infertility after 40: Influence of paternal age on fertility. Maturitas. 2014;78:22-9.

61. Agarwal A, Said TM. Role of sperm chromatin abnormalities and DNA damage in male infertility. Hum Reprod Update. 2003;9:331-45.

62. Sharma RK, Said T, Agarwal A. Sperm DNA damage and its clinical relevance in assessing reproductive outcome. Asian J Androl. 2004;6:139-48.

63. Moustafa MH, Sharma RK, Thornton J, Mascha E, Abdel-Hafez MA, Thomas AJ, et al. Relationship between ROS production, apoptosis and DNA denaturation in spermatozoa from patients examined for infertility. Hum Reprod. 2004;19:129-38.

64. De luliis GN, Thomson LK, Mitchell LA, Finnie JM, Koppers AJ, Hedges A, et al. DNA damage in human spermatozoa is highly correlated with the efficiency of chromatin remodeling and the formation of 8-hydroxy-2'-deoxyguanosine, a marker of oxidative stress. Biol Reprod. 2009;81:517-24.

65. Zini A, Sigman M. Are tests of sperm DNA damage clinically useful? Pros Cons J Androl. 2009;30:219-29.

66. Zini A, Phillips S, Courchesne A, Boman JM, Baazeem A, Bissonnette F, et al. Sperm head morphology is related to high deoxyribonucleic acid stainability assessed by sperm chromatin structure assay. Fertil Steril. 2009;91:2495-500.

67. Zini A, Albert O, Robaire B. Assessing sperm chromatin and DNA damage: clinical importance and development of standards. Andrology. 2014;2:322-5. 
68. Alshahrani S, Agarwal A, Assidi M, Abuzenadah AM, Durairajanayagam D, Ayaz A, et al. Infertile men older than 40 years are at higher risk of sperm DNA damage. Reprod Biol Endocrinol. 2014;12:103.

69. Aitken RJ, Bronson R, Smith TB, De luliis GN. The source and significance of DNA damage in human spermatozoa; a commentary on diagnostic strategies and straw man fallacies. Mol Hum Reprod. 2013;19:475-85.

70. Smith TB, Baker MA, Connaughton HS, Habenicht U, Aitken RJ. Functional deletion of Txndc2 and Txndc3 increases the susceptibility of spermatozoa to age-related oxidative stress. Free Radic Biol Med. 2013;65:872-81.

71. Aitken RJ. Age, the environment and our reproductive future: bonking baby boomers and the future of sex. Reproduction. 2013;147:S1-11.

72. Aitken RJ, Smith TB, Jobling MS, Baker MA, De luliis GN. Oxidative stress and male reproductive health. Asian J Androl. 2014;16:31-8.

73. Treulen F, Uribe P, Boguen R, Villegas JV. Mitochondrial permeability transition increases reactive oxygen species production and induces DNA fragmentation in human spermatozoa. Hum Reprod. 2015;30:767-76.

74. Evenson DP, Larson KL, Jost LK. Sperm chromatin structure assay: its clinical use for detecting sperm DNA fragmentation in male infertility and comparisons with other techniques. J Androl. 2002;23:25-43.

75. Evenson D, Wixon R. Meta-analysis of sperm DNA fragmentation using the sperm chromatin structure assay. Reprod Biomed Online. 2006;12:466-72.

76. Sharma RK, Sabanegh E, Mahfouz R, Gupta S, Thiyagarajan A, Agarwal A. TUNEL as a test for sperm DNA damage in the evaluation of male infertility. Urology. 2010;76:1380-6.

77. Paasch U, Sharma RK, Gupta AK, Grunewald S, Mascha EJ, Thomas Jr AJ, et al. Cryopreservation and thawing is associated with varying extent of activation of apoptotic machinery in subsets of ejaculated human spermatozoa. Biol Reprod. 2004;71:1828-37.

78. Wolf BB, Schuler M, Echeverri F, Green DR. Caspase-3 is the primary activator of apoptotic DNA fragmentation via DNA fragmentation factor-45/inhibitor of caspase-activated DNase inactivation. J Biol Chem. 1999;274:30651-6.

79. Baccetti B, Collodel G, Piomboni P. Apoptosis in human ejaculated sperm cells (notulae seminologicae 9). J Submicrosc Cytol Pathol. 1996;28:587-96.

80. Sakkas D, Mariethoz E, Manicardi G, Bizzaro D, Bianchi PG, Bianchi U. Origin of DNA damage in ejaculated human spermatozoa. Rev Reprod. 1999:4:31-7.

81. Sakkas D, Moffat O, Manicardi GC, Mariethoz E, Tarozzi N, Bizzaro D. Nature of DNA damage in ejaculated human spermatozoa and the possible involvement of apoptosis. Biol Reprod. 2002;66:1061-7.

82. Sakkas D, Seli E, Bizzaro D, Tarozzi N, Manicardi GC. Abnormal spermatozoa in the ejaculate: abortive apoptosis and faulty nuclear remodelling during spermatogenesis. Reprod Biol Online. 2004;7:428-32.

83. Shen HM, Dai J, Chia SE, Lim A, Ong CN. Detection of apoptotic alterations in sperm in subfertile patients and their correlations with sperm quality. Hum Reprod. 2002;17:1266-73.

84. El-Domyati MM, Al-Din AB, Barakat MT, El-Fakahany HM, Xu J, Sakkas D. Deoxyribonucleic acid repair and apoptosis in testicular germ cells of aging fertile men: the role of the poly(adenosine diphosphate-ribosyl)ation pathway. Fertil Steril. 2009;91:2221-9.

85. Moskovtsev SI, Alladin N, Lo KC, Jarvi K, Mullen JB, Librach CL. A comparison of ejaculated and testicular spermatozoa aneuploidy rates in patients with high sperm DNA damage. Syst Biol Reprod Med. 2012;58:142-8.

86. Brahem S, Mehdi M, Elghezal H, Saad A. Analysis of sperm aneuploidies and DNA fragmentation in patients with globozoospermia or with abnormal acrosomes. Urology. 2011;77:1343-8.

87. Brahem S, Mehdi M, Elghezal H, Saad A. Study of aneuploidy rate and sperm DNA fragmentation in large-headed, multiple-tailed spermatozoa. Andrologia. 2012;44:130-5.

88. Moskovtsev SI, Willis J, White J, Mullen JB. Sperm DNA damage: correlation to severity of semen abnormalities. Urology. 2009;74:789-93.

89. Singh NP, Muller CH, Berger RE. Effects of age on DNA double-strand breaks and apoptosis in human sperm. Fertil Steril. 2003;80:1420-30.

90. Spano M, Bonde JP, Hjollund HI, Kolstad HA, Cordelli E, Leter G. Sperm chromatin damage impairs human fertility. The Danish First Pregnancy Planner Study Team. Fertil Steril. 2000;73:43-50.

91. Das M, Al-Hathal N, San-Gabriel M, Phillips S, Kadoch IJ, Bissonnette F, et al. High prevalence of isolated sperm DNA damage in infertile men with advanced paternal age. J Assist Reprod Genet. 2013;30:843-8.

92. Barroso G, Morshedi M, Oehninger S. Analysis of DNA fragmentation, plasma membrane translocation of phosphatidylserine and oxidative stress in human spermatozoa. Hum Reprod. 2000;15:1338-44.
93. Johnson SL, Dunleavy J, Gemmell NJ, Nakagawa S. Consistent age-dependent declines in human semen quality: a systematic review and meta-analysis. Ageing Res Rev. 2015;19:22-33.

94. Colin-Valenzuela A, Gómez-López N, Avila-Lombardo R, Barroso-Villa G. [Impact of male aging in the functional capacity of sperm through the expression of phosphatidyl serine and oligonucleomas]. Ginecol Obstet Mex. 2010;78:669-76. Spanish.

95. Giwercman A, Lindstedt L, Larsson M, Bungum M, Spano M, Levine RJ, et al. Sperm chromatin structure assay as an independent predictor of fertility invivo: a case-control study. Int J Androl. 2010;33:e221-7.

96. Loft S, Kold-Jensen T, Hjollund NH, Giwercman A, Gyllemborg J, Ernst E, et al. Oxidative DNA damage in human sperm influences time to pregnancy. Hum Reprod. 2003;18:1265-72.

97. Zini A. Are sperm chromatin and DNA defects relevant in the clinic? Syst Biol Reprod Med. 2011;57:78-85.

98. Bungum M, Humaidan P, Axmon A, Spano M, Bungum L, Erenpreiss J, et al. Sperm DNA integrity assessment in prediction of assisted reproduction technology outcome. Hum Reprod. 2007;22:174-9.

99. Collins JA, Barnhart KT, Schlegel PN. Do sperm DNA integrity tests predict pregnancy with in vitro fertilization? Fertil Steril. 2008;89:823-31.

100. Practice Committee of the American Society for Reproductive Medicine. The clinical utility of sperm DNA integrity testing: a guideline. Fertil Steril. 2013;99:673-7.

101. Robinson L, Gallos ID, Conner SJ, Rajkhowa M, Miller D, Lewis S, et al. The effect of sperm DNA fragmentation on miscarriage rates: a systematic review and meta-analysis. Hum Reprod. 2012;27:2908-17.

102. Nijs M, De Jonge C, Cox A, Janssen M, Bosmans E, Ombelet W. Correlation between male age, WHO sperm parameters, DNA fragmentation, chromatin packaging and outcome in assisted reproduction technology. Andrologia. 2011:43:174-9.

103. Zhao J, Zhang Q, Wang Y, Li Y. Whether sperm deoxyribonucleic acid fragmentation has an effect on pregnancy and miscarriage after in vitro fertilization/intracytoplasmic sperm injection: a systematic review and meta-analysis. Fertil Steril. 2014;102:998-1005.

104. Kuhnert B, Nieschlag E. Reproductive functions of the ageing male. Hum Reprod Update. 2004;10:327-39.

105. Katib AA, Al-Hawsawi K, Motair W, Bawa AM. Secondary infertility and the aging male, overview. Cent Eur J Urol. 2014;67:184-8.

106. Morris ID, Ilott S, Dixon L, Brison DR. The spectrum of DNA damage in human sperm assessed by single cell gel electrophoresis (Comet assay) and its relationship to fertilization and embryo development. Hum Reprod. 2002;17:990-8

107. Borini A, Tarozzi N, Bizzaro D, Bonu MA, Fava L, Flamigni C. Sperm DNA fragmentation: paternal effect on early post-implantation embryo development in ART. Hum Reprod. 2006;21:2876-81.

108. Simon L, Murphy K, Shamsi MB, Liu L, Emery B, Aston Kl. Paternal influence of sperm DNA integrity on early embryonic development. Hum Reprod. 2014;29:2402-12.

109. Frattarelli JL, Miller KA, Miller BT, Elkind-Hirsch K, Scott Jr RT. Male age negatively impacts embryo development and reproductive outcome in donor oocyte assisted reproductive technology cycles. Fertil Steril. 2008;90:97-103.

110. Bellver J, Garrido N, Remohí J, Pellicer A, Meseguer M. Influence of paternal age on assisted reproduction outcome. Reprod Biomed Online. 2008;17:595-604.

111. Paulson RJ, Milligan RC, Sokol RZ. The lack of influence of age on male fertility. Am J Obstet Gynecol. 2001;184:818-22.

112. Spandorfer SD, Avrech OM, Colombero LT, Palermo GD, Rosenwaks Z. Effect of parental age on fertilization and pregnancy characteristics in couples treated by intracytoplasmic sperm injection. Hum Reprod. 1998;13:334-8.

113. Dain $L$, Auslander R, Dirnfeld M. The effect of paternal age on assisted reproduction outcome. Fertil Steril. 2011;95:1-8.

114. Blackburn EH, Gall JG. A tandemly repeated sequence at the termini of the extrachromosomal ribosomal RNA genes in Tetrahymena. J Mol Biol. 1978;120:33-53.

115. Blackburn EH. Switching and signaling at the telomere. Cell. 2001;106:661-73.

116. Lindsey J, McGill NI, Lindsey LA, Green DK, Cooke HJ. In vivo loss of telomeric repeats with age in humans. Mutat Res. 1991;256:45-8.

117. Cawthon RM, Smith KR, O'Brien E, Sivatchenko A, Kerber RA. Association between telomere length in blood and mortality in people aged 60 years or older. Lancet. 2003;361:393-5. 
118. Bakaysa SL, Mucci LA, Slagboom PE, Boomsma DI, McClearn GE, Johansson B, et al. Telomere length predicts survival independent of genetic influences. Aging Cell. 2007;6:769-74.

119. Kimura M, Hjelmborg JV, Gardner JP, Bathum L, Brimacombe M, Lu X, et al. Telomere length and mortality: a study of leukocytes in elderly Danish twins. Am J Epidemiol. 2008;167:799-806.

120. Daniali L, Benetos A, Susser E, Kark JD, Labat C, Kimura M, et al. Telomeres shorten at equivalent rates in somatic tissues of adults. Nat Commun. 2013;4:1597

121. Aubert G, Lansdorp PM. Telomeres and aging. Physiol Rev. 2008;88:557-79.

122. Blackburn EH, Greider CW, Szostak JW. Telomeres and telomerase: the path from maize, Tetrahymena and yeast to human cancer and aging. Nat Med. 2006;12:1133-8.

123. Dolcetti R, De Rossi A. Telomere/telomerase interplay in virus-driven and virus-independent lymphomagenesis: pathogenetic and clinical implications. Med Res Rev. 2012;32:233-53.

124. Unryn BM, Cook LS, Riabowol KT. Paternal age is positively linked to telomere length of children. Aging Cell. 2005;4:97-101.

125. DeMeyer T, Rietzschel ER, DeBuyzere ML, DeBacquer D, Van Criekinge W, De Backer GG, et al. Paternal age at birth is an important determinant of offspring telomere length. Hum Mol Genet. 2007;16:3097-102.

126. Njajou OT, Cawthon RM, Damcott CM, Wu SH, Ott S, Garant MJ, et al. Telomere length is paternally inherited and is associated with parental lifespan. Proc Natl Acad Sci U S A. 2007;104:12135-9.

127. Kimura M, Cherkas LF, Kato BS, Demissie S, Hjelmborg JB, Brimacombe M, et al. Offspring's leukocyte telomere length, paternal age, and telomere elongation in sperm. PLoS Genet. 2008;4:e37.

128. Arbeev KG, Hunt SC, Kimura M, Aviv A, Yashin Al. Leukocyte telomere length, breast cancer risk in the offspring: the relations with father's age at birth. Mech Ageing Dev. 2011;132:149-53.

129. Prescott J, Du M, Wong JY, Han J, De Vivo I. Paternal age at birth is associated with offspring leukocyte telomere length in the nurses' health study. Hum Reprod. 2012;27:3622-31.

130. Aviv A, Susser E. Leukocyte telomere length and the father's age enigma: implications for population heath and for life course. Int J Epidemiol. 2013:42:457-62.

131. Aston Kl, Hunt SC, Susser E, Kimura M, Factor-Litvak P, Carrell D, et al. Divergence of sperm and leukocyte age-dependent telomere dynamics: implications for male-driven evolution of telomere length in humans. Mol Hum Reprod. 2012;18:517-22.

132. Ferlin A, Rampazzo E, Rocca MS, Keppel S, Frigo AC, De Rossi A, et al. In young men sperm telomere length is related to sperm number and parental age. Hum Reprod. 2013;28:3370-6.

133. Eisenberg DT, Hayes MG, Kuzawa CW. Delayed paternal age of reproduction in humans is associated with longer telomeres across two generations of descendants. Proc Natl Acad Sci U S A. 2012;109:10251-6.

134. Nordfäll K, Svenson U, Norrback KF, Adolfsson R, Roos G. Large-scale parent-child comparison confirms a strong paternal influence on telomere length. Eur J Hum Genet. 2010;18:385-9.

135. Baird DM, Britt-Compton B, Rowson J, Amso NN, Gregory L, Kipling D. Telomere instability in the male germline. Hum Mol Genet. 2006;15:45-51.

136. Zalenskaya IA, Zalensky AO. Telomeres in mammalian male germline cells. Int Rev Cytol. 2002;218:37-67.

137. Riou L, Bastos H, Lassalle B, Coureuil M, Testart J, Boussin FD, et al. The telomerase activity of adult mouse testis resides in the spermatogonial alpha6-integrin-positive side population enriched in germinal stem cells. Endocrinology. 2005;146:3926-32.

138. Thilagavathi J, Kumar M, Mishra SS, Venkatesh S, Kumar R, Dada R. Analysis of sperm telomere length inmenwith idiopathic infertility. Arch Gynecol Obstet. 2013;287:803-7.

139. Siderakis $M$, Tarsounas $M$. Telomere regulation and function during meiosis. Chromosome Res. 2007;15:667-79.

140. Grégoire MC, Massonneau J, Simard O, Gouraud A, Brazeau MA, Arguin M, et al. Male-driven de novo mutations in haploid germ cells. Mol Hum Reprod. 2013;19:495-9.

141. Lowe X, Eskenazi B, Nelson DO, Kidd S, Alme A, Wyrobek AJ. Frequency of $X Y$ sperm increases with age in fathers of boys with Klinefelter syndrome. Am J Hum Genet. 2001;69:1046-54.

142. Kong A, Frigge ML, Masson G, Besenbacher S, Sulem P, Magnusson G, et al. Rate of de novo mutations and the importance of father's age to disease risk. Nature. 2012;488:471-5.
143. Vogel F, Rathenberg R. Spontaneous mutation in man. Adv Hum Genet. 1975:5:223-318.

144. Drost JB, Lee WR. Biological basis of germline mutation: comparisons of spontaneous germline mutation rates among drosophila, mouse, and human. Environ Mol Mutagen. 1995;26:48-64.

145. Chianese C, Brilli S, Krausz C. Genomic changes in spermatozoa of the aging male. Adv Exp Med Biol. 2014;791:13-26.

146. Glaser RL, Jiang W, Boyadjiev SA, Tran AK, Zachary AA, Van Maldergem L, et al. Paternal origin of FGFR2 mutations in sporadic cases of Crouzon syndrome and Pfeiffer syndrome. Am J Hum Genet. 2000;66:768-77.

147. Goriely A, Wilkie AO. Paternal age effect mutations and selfish spermatogonial selection: causes and consequences for human disease. Adv Exp Med Biol. 2012;90:175-200.

148. Rannan-Eliya SV, Taylor IB, De Heer IM, Van Den Ouweland AM, Wall SA, Wilkie AO. Paternal origin of FGFR3 mutations in Muenke-type craniosynostosis. Hum Genet. 2004;115:200-7

149. Wyrobek AJ, Eskenazi B, Young S, Arnheim N, Tiemann-Boege I, Jabs EW, et al. Advancing age has differential effects on DNA damage, chromatin integrity, gene mutations, and aneuploidies in sperm. Proc Natl Acad Sci U S A. 2006;103:9601-6.

150. McLachlan Rl, O'Bryan MK. Clinical Review\#: State of the art for genetic testing of infertile men. J Clin Endocrinol Metab. 2010;95:1013-24.

151. Johnson RE, Washington MT, Prakash S, Prakash L. Fidelity of human DNA polymerase $h^{*}$. J Biol Chem. 2000;275:7447-50.

152. Makova KD, Yang S, Chiaromonte F. Insertions and deletions are male biased too: a whole-genome analysis in rodents. Genome Res. 2004;14:567-73.

153. Kato T, Yamada $K$, Inagaki H, Kogo H, Ohye T, Emanuel BS, et al. Age has no effect on de novo constitutional $t(11 ; 22)$ translocation frequency in sperm. Fertil Steril. 2007:88:1446-8.

154. Bashamboo A, Ferraz-de-Souza B, Lourenço D, Lin L, Sebire NJ, Montjean D, et al. Human male infertility associated with mutations in NR5A1 encoding steroidogenic factor 1. Am J Hum Genet. 2010;87:505-12.

155. Sun C, Skaletsky H, Birren B, Devon K, Tang Z, Silber S, et al. An azoospermic man with a de novo point mutation in the Y-chromosomal gene USP9Y. Nat Genet. 1999;23:429-32.

156. Templado C, Donate A, Giraldo J, Bosch M, Estop A. Advanced age increases chromosome structural abnormalities in human spermatozoa. Eur J Hum Genet. 2011;19:145-51

157. Hassold T, Hunt P. To err (meiotically) is human: the genesis of human aneuploidy. Nat Rev Genet. 2001;2:280-91.

158. Regan L, Rai R. Epidemiology and the medical causes of miscarriage. Baillieres Best Pract Res Clin Obstet Gynaecol. 2000;14:839-54.

159. Griffin DK, Abruzzo MA, Millie EA, Feingold E, Hassold TJ. Sex ratio in normal and disomic sperm: evidence that the extra chromosome 21 preferentially segregates with the Y chromosome. Am J Hum Genet. 1996;59:1108-13.

160. Mclntosh GC, Olshan AF, Baird PA. Paternal age and the risk of birth defects in offspring. Epidemiology. 1995;6:282-8.

161. Hatch $M$, Kline J, Levin B, Hutzler M, Warburton D. Paternal age and trisomy among spontaneous abortions. Hum Genet. 1990;85:355-61.

162. Eggermann T, Nothen MM, Eiben B, Hofmann D, Hinkel K, Fimmers R, et al. Trisomy of human chromosome 18: molecular studies on parental origin and cell stage of nondisjunction. Hum Genet. 1996;97:218-23.

163. Bugge M, Collins A, Hertz JM, Eiberg H, Lundsteen C, Brandt CA, et al. Non-disjunction of chromosome 13. Hum Mol Genet. 2007;16:2004-10.

164. Zaragoza MV, Jacobs PA, James RS, Rogan P, Sherman S, Hassold T. Nondisjunction of human acrocentric chromosomes: studies of 432 trisomic fetuses and liveborns. Hum Genet. 1994;94:411-7.

165. Lorda-Sanchez I, Binkert F, Maechler M, Robinson WP, Schinzel AA. Reduced recombination and paternal age effect in Klinefelter syndrome. Hum Genet. 1992;89:524-30.

166. Thomas NS, Collins AR, Hassold TJ, Jacobs PA. A reinvestigation of non-disjunction resulting in 47, XXY males of paternal origin. Eur J Hum Genet. 2000;8:805-8.

167. Carothers AD, Frackiewicz A, De Mey R, Collyer S, Polani PE, Osztovics M, et al. A collaborative study of the aetiology of Turner syndrome. Ann Hum Genet. 1980;43:355-68.

168. Mathur A, Stekol L, Schatz D, MacLaren NK, Scott ML, Lippe B. The parental origin of the single $\mathrm{X}$ chromosome in Turner syndrome: lack of correlation with parental age or clinical phenotype. Am J Hum Genet. 1991;48:682-6.

169. López-Otín C, Blasco MA, Partridge L, Serrano M, Kroemer G. The Hallmarks of Aging. Cell. 2013;153:1194-217. 
170. Moskalev AA, Shaposhnikov MV, Plyusnina EN, Zhavoronkov A, Budovsky A, Yanai $\mathrm{H}$, et al. The role of DNA damage and repair in aging through the prism of Koch-like criteria. Ageing Res Rev. 2013;12:661-84.

171. Fumagalli M, Rossiello F, Clerici M, Barozzi S, Cittaro D, Kaplunov JM, et al. Telomeric DNA damage is irreparable and causes persistent DNA-damageresponse activation. Nat Cell Biol. 2012;14:355-65.

172. Rossiello F, Herbig U, Longhese MP, Fumagalli M, d'Adda di Fagagna F. Irreparable telomeric DNA damage and persistent DDR signalling as a shared causative mechanism of cellular senescence and ageing. Curr Opin Genet Dev. 2014;26C:89-95.

173. Callaway E. Fathers bequeath more mutations as they age. Nature. 2012;488:439.

174. Sikora E, Arendt T, Bennett M, Narita M. Impact of cellular senescence signature on ageing research. Ageing Res Rev. 2011;10:146-52.

175. Kotaja N. MicroRNAs and spermatogenesis. Fertil Steril. 2014;101:1552-62.

176. Harries LW. MicroRNAs as Mediators of the Ageing Process. Gene. 2014:5:656-70.

177. Belleannee C, Legare C, Calvo E, Thimon V, Sullivan R. microRNA signature is altered in both human epididymis and seminal microvesicles following vasectomy. Hum Reprod. 2013;28:1455-67.

178. Yan Y, Salazar TE, Dominguez 2nd JM, Nguyen DV, Li Calzi S, Bhatwadekar AD, et al. Dicer expression exhibits a tissue-specific diurnal pattern that is lost during aging and in diabetes. PLoS One. 2013;8:e80029.

179. Turner $\Pi$ T. On the epididymis and its role in the development of the fertile ejaculate. J Androl. 1995;16:292-8.

180. Jones RC. To store or mature spermatozoa? The primary role of the epididymis. Int J Androl. 1999;22:57-67.

181. Zhang J, Liu Q, Zhang W, Li J, Li Z, Tang Z, et al. Comparative profiling of genes and miRNAs expressed in the newborn, young adult, and aged human epididymides. Acta Biochim Biophys Sin (Shanghai). 2010:42:145-53.

182. Zitzmann M. Effects of age on male fertility. Best Pract Res Clin Endocrinol Metab. 2013;27:617-28.

183. Dada R, Kumar M, Jesudasan R, Fernandez JL, Gosalvez J, Agarwal A. Epigenetics and its role in male infertility. J Assist Reprod Genet. 2012;29:213-23.

184. Marques CJ, Carvalho F, Sousa M, Barros A. Genomic imprinting in disruptive spermatogenesis. Lancet. 2004;363:1700-2.

185. El Hajj N, Zechner U, Schneider E, Tresch A, Gromoll J, Hahn T, et al. Methylation status of imprinted genes and repetitive elements in sperm DNA from infertile males. Sex Dev. 2011;5:60-9.

186. Kobayashi H, Sato A, Otsu E, Hiura H, Tomatsu C, Utsunomiya T, et al. Aberrant DNA methylation of imprinted loci in sperm from oligospermic patients. Hum Mol Genet. 2007;16:2542-51.

187. Sato A, Hiura H, Okae H, Miyauchi N, Abe Y, Utsunomiya T, et al. Assessing loss of imprint methylation in sperm from subfertile men using novel methylation polymerase chain reaction Luminex analysis. Fertil Steril. 2011;95:129-34.

188. Boissonnas CC, Abdalaoui HE, Haelewyn V, Fauque P, Dupont JM, Gut I, et al. Specific epigenetic alterations of IGF2-H19 locus in spermatozoa from infertile men. Eur J Hum Genet. 2010;18:73-80.

189. Houshdaran S, Cortessis VK, Siegmund K, Yang A, Laird PW, Sokol RZ. Widespread epigenetic abnormalities suggest a broad DNA methylation erasure defect in abnormal human sperm. PLoS One. 2007;2:e1289.

190. Montjean D, Ravel C, Benkhalifa M, Cohen-Bacrie P, Berthaut I, Bashamboo A, et al. Methylation changes in mature sperm deoxyribonucleic acid from oligozoospermic men: assessment of genetic variants and assisted reproductive technology outcome. Fertil Steril. 2013;100:1241-7.

191. Benchaib M, Braun V, Lornage J, Hadj S, Salle B, Lejeune H, et al. Sperm DNA fragmentation decreases the pregnancy rate in an assisted reproductive technique. Hum Reprod. 2003;18:1023-8.

192. Benchaib M, Braun V, Ressnikof D, Lornage J, Durand P, Niveleau A, et al. Influence of global sperm DNA methylation on IVF results. Hum Reprod. 2005;20:768-73.

193. Beard C, Li E, Jaenisch R. Loss of methylation activates Xist in somatic but not in embryonic cells. Genes Dev. 1995;9:2325-34.

194. Katz-Jaffe MG, Parks J, McCallie B, Schoolcraft WB. Aging sperm negatively impacts in vivo and in vitro reproduction: a longitudinal murine study. Fertil Steril. 2013;100:262-8.

195. Nanassy L, Liu L, Griffin J, Carrell DT. The clinical utility of the protamine 1/protamine 2 ratio in sperm. Protein Pept Letters. 2011;18:772-7.

196. Jenkins TG, Aston Kl, Cairns BR, Carrell DT. Paternal aging and associated intraindividual alterations of global sperm 5-methylcytosine and 5-hydroxymethylcytosine levels. Fertil Steril. 2013;100:945-51.
197. Dan B, Pelc K, Christophe C. What would the brain look like in Angelman syndrome? Eur J Paediatr Neurol. 2009;13:269-70.

198. DeBaun MR, Siegel MJ, Choyke PL. Nephromegaly in infancy and early childhood: a risk factor for Wilms tumor in Beckwith-Wiedemann syndrome. J Pediatr. 1998;132:401-4.

199. Gosden R, Trasler J, Lucifero D, Faddy M. Rare congenital disorders, imprinted genes, and assisted reproductive technology. Lancet. 2003;361:1975-7.

200. Weinberg W. Zur Verebung des Zwergwuchses. Archiv Fuer Rassen und Gesellschafts-Biologie. 1912;9:710.

201. Penrose LS. Parental age and mutation. Lancet. 1955;269:312-3.

202. Crow JF. Age and sex effects on human mutation rates: an old problem with new complexities. J Radiat Res. 2006;47:B75-82.

203. Torrey EF, Buka S, Cannon TD, Goldstein JM, Seidman LJ, Liu T, et al. Paternal age as a risk factor for schizophrenia: how important is it? Schizophr Res. 2009;114:1-5.

204. de La Rochebrochard E, de Mouzon J, Thepot F, Thonneau P. Fathers over 40 and increased failure to conceive: the lessons of in vitro fertilization in France. Fertil Steril. 2006:85:1420-4.

205. Buizer-Voskamp JE, Laan W, Staal WG, Hennekam EA, Aukes MF, Termorshuizen $F$, et al. Paternal age and psychiatric disorders: findings from a Dutch population registry. Schizophr Res. 2011;129:128-32.

206. Sipos A, Rasmussen F, Harrison G, Tynelius P, Lewis G, Leon DA, et al. Paternal age and schizophrenia: a population based cohort study. BMJ. 2004;329:1070.

207. Miller B, Messias E, Miettunen J, Alaraisanen A, Jarvelin MR, et al. Meta-analysis of paternal age and schizophrenia risk in male versus female offspring. Schizophr Bull. 2011;37:1039-47.

208. Frans EM, McGrath JJ, Sandin S, Lichtenstein P, Reichenberg A, Langstrom N, et al. Advanced paternal and grandpaternal age and schizophrenia: a three-generation perspective. Schizophr Res. 2011;133:120-4.

209. American Psychiatric Association. Diagnostic and Statistical Manual of Mental Disorders. 5th ed. DSM-5. Washington, DC, 2013.

210. Murray CJ, Lopez AD. Evidence-based health policy-lessons from the Global Burden of Disease Study. Science. 1996;274:740-3.

211. Malaspina D, Corcoran C, Fahim C, Berman A, Harkavy-Friedman J, Yale S, et al. Paternal age and sporadic schizophrenia: evidence for de novo mutations. Am J Med Genet. 2002;114:299-303.

212. Xu B, Roos JL, Levy S, van Rensburg EJ, Gogos JA, Karayiorgou M. Strong association of de novo copy number mutations with sporadic schizophrenia. Nat Genet. 2008;40:880-5.

213. Malaspina D, Harlap S, Fennig S, Heiman D, Nahon D, Feldman D, et al. Advancing paternal age and the risk of schizophrenia. Arch Gen Psychiatry. 2001;58:361-7.

214. Tsuchiya KJ, Takagai S, Kawai M, Matsumoto H, Nakamura K, Minabe Y, et al. Advanced paternal age associated with an elevated risk for schizophrenia in offspring in a Japanese population. Schizophr Res. 2005;76:337-42.

215. Wohl M, Gorwood P. Paternal ages below or above 35 years old are associated with a different risk of schizophrenia in the offspring. Eur Psychiatry. 2007;22:22-6.

216. Petersen L, Mortensen PB, Pedersen CB. Paternal age at birth of first child and risk of schizophrenia. Am J Psychiatry. 2011;168:82-8.

217. Moore T, Haig D. Genomic imprinting in mammalian development: a parental tug-of-war. Trends Genet. 1991;7:45-9.

218. Perrin MC, Brown AS, Malaspina D. Aberrant epigenetic regulation could explain the relationship of paternal age to schizophrenia. Schizophr Bull. 2007;33:1270-3.

219. Frans EM, Sandin S, Reichenberg A, Lichtenstein P, Langstrom N, Hultman CM. Advancing paternal age and bipolar disorder. Arch Gen Psychiatry. 2008;65:1034-40.

220. Menezes PR, Lewis G, Rasmussen F, Zammit S, Sipos A, Harrison GL, et al. Paternal and maternal ages at conception and risk of bipolar affective disorder in their offspring. Psychol Med. 2010;40:477-85.

221. Kirov G, Pocklington AJ, Holmans P, Ivanov D, Ikeda M, Ruderfer D, et al. De novo CNV analysis implicates specific abnormalities of postsynaptic signalling complexes in the pathogenesis of schizophrenia. Mol Psychiatry. 2012;17:142-53.

222. Kaminsky Z, Tochigi M, Jia P, Pal M, Mill J, Kwan A, et al. A multi-tissue analysis identifies HLA complex group 9 gene methylation differences in bipolar disorder. Mol Psychiatry. 2012;17:728-40.

223. Mohammed AR, Mohammed SA, AbdulFatah AM. Congenital Anomalies among Children: Knowledge and Attitude of Egyptian and Saudi Mothers. Biol Agr Healthcare. 2013;3:2224-3208. 
224. Anagnostou E, Taylor MJ. Review of neuroimaging in autism spectrum disorders: what have we learned and where we go from here. Mol Autism. 2011;2:4.

225. Mandell DS, Novak MM, Zubritsky CD. Factors associated with age of diagnosis among children with autism spectrum disorders. Pediatrics. 2005;116:1480-6.

226. Reichenberg A, Gross R, Weiser M, Bresnahan M, Silverman J, Harlap S, et al. Advancing paternal age and autism. Arch Gen Psychiatry. 2006;63:1026-32.

227. Hultman CM, Sandin S, Levine SZ, Lichtenstein P, Reichenberg A. Advancing paternal age and risk of autism: new evidence from a population-based study and a meta-analysis of epidemiological studies. Mol Psychiatry. 2011;16:1203-12

228. Momand JR, Xu G, Walter CA. The paternal age effect: a multifaceted phenomenon. Biol Reprod. 2013;88:108.

229. Durkin MS, Maenner MJ, Newschaffer CJ, Lee LC, Cunniff CM, Daniels JL, et al. Advanced parental age and the risk of autism spectrum disorder. Am J Epidemiol. 2008;168:1268-76.

230. Frans EM, Sandin S, Reichenberg A, Langstrom N, Lichtenstein P, McGrath J, et al. Autism risk across generations: a population-based study of advancing grandpaternal and paternal age. JAMA Psychiatry. 2013;70:516-21.

231. Sampino S, Juszczak GR, Zacchini F, Swiergiel AH, Modlinski JA, Loi $P$, et al. Grand-paternal age and the development of autism-like symptoms in mice progeny. Transl Psychiatry. 2014;4:e386.

232. O'Roak BJ, Vives L, Girirajan S, Karakoc E, Krumm N, Coe BP, et al. Sporadic autism exomes reveal a highly interconnected protein network of de novo mutations. Nature. 2012;485:246-50

233. Sanders SJ, Murtha MT, Gupta AR, Murdoch JD, Raubeson MJ, Willsey AJ, et al. De novo mutations revealed by whole-exome sequencing are strongly associated with autism. Nature. 2012:485:237-41.

234. Yoon SR, Qin J, Glaser RL, Jabs EW, Wexler NS, Sokol R, et al. The ups and downs of mutation frequencies during aging can account for the Apert syndrome paternal age effect. PLoS Genet. 2009;5:e1000558.

235. Glaser RL, Broman KW, Schulman RL, Eskenazi B, Wyrobek AJ, Jabs EW. The paternal-age effect in Apert syndrome is due, in part, to the increased frequency of mutations in sperm. Am J Hum Genet. 2003;73:939-47.

236. Risch N, Reich EW, Wishnick MM, McCarthy JG. Spontaneous mutation and parental age in humans. Am J Hum Genet. 1987;41:218-48.

237. Tiemann-Boege I, Navidi W, Grewal R, Cohn D, Eskenazi B, Wyrobek AJ, et al. The observed human sperm mutation frequency cannot explain the achondroplasia paternal age effect. Proc Natl Acad Sci U S A. 2002:99:14952-7.

238. Riccardi VM, Dobson 2nd CE, Chakraborty R, Bontke C. The pathophysiology of neurofibromatosis: IX. Paternal age as a factor in the origin of new mutations. Am J Med Genet. 1984;18:169-76.

239. Bunin GR, Needle M, Riccardi VM. Paternal age and sporadic neurofibromatosis 1: a case-control study and consideration of the methodologic issues. Genet Epidemiol. 1997;14:507-16.

240. Blumsohn A, McAllion SJ, Paterson CR. Excess paternal age in apparently sporadic osteogenesis imperfecta. Am J Med Genet. 2001;100:280-6.

241. Heck JE, Lombardi CA, Meyers TJ, Cockburn M, Wilhelm M, Ritz B. Perinatal characteristics and retinoblastoma. Cancer Causes Control. 2012;23:1567-75.

242. Toriello HV, Meck JM, Professional P, Guidelines C. Statement on guidance for genetic counseling in advanced paternal age. Genet Med. 2008;10:457-60.

243. Bille C, Skytthe A, Vach W, Knudsen LB, Andersen AM, Murray JC, et al. Parent's age and the risk of oral clefts. Epidemiology. 2005;16:311-6.

244. Hemminki K, Kyyrönen P, Vaittinen P. Parental age as a risk factor of childhood leukemia and brain cancer in offspring. Epidemiology. 1999:10:271-5

245. Hemminki K, Kyyronen P. Parental age and risk of sporadic and familial cancer in offspring: implications for germ cell mutagenesis. Epidemiology. 1999;10:747-51.

246. Zhu JL, Madsen KM, Vestergaard M, Olesen AV, Basso O, Olsen J. Paternal age and congenital malformations. Hum Reprod. 2005;20:3173-7.

247. Wu Y, Liu X, Luo H, Deng W, Zhao G, Wang Q, et al. Advanced paternal age increases the risk of schizophrenia and obsessive-compulsive disorder in a Chinese Han population. Psychiatry Res. 2012;198:353-9.

248. Yip BH, Pawitan Y, Czene K. Parental age and risk of childhood cancers: a population-based cohort study from Sweden. Int J Epidemiol. 2006;35:1495-503.

249. McGrath JJ, Petersen L, Agerbo E, Mors O, Mortensen PB, Pedersen CB. A comprehensive assessment of parental age and psychiatric disorders. JAMA Psychiatry. 2014;71:301-9.
250. Ford WC, North K, Taylor H, Farrow A, Hull MG, Golding J. Increasing paternal age is associated with delayed conception in a large population of fertile couples: evidence for declining fecundity in older men. The ALSPAC Study Team (Avon Longitudinal Study of Pregnancy and Childhood). Hum Reprod. 2000;15:1703-8.

251. Olsen J. Subfecundity according to the age of the mother and the father. Dan Med Bull. 1990;37:281-2.

252. De La Rochebrochard E, McElreavey K, Thonneau P. Paternal age over 40 years: the "amber light" in the reproductive life of men? J Androl. 2003;24:459-65.

253. Hassan MA, Killick SR. Effect of male age on fertility: evidence for the decline in male fertility with increasing age. Fertil Steril. 2003;79:1520-7.

254. Dunson DB, Colombo B, Baird DD. Changes with age in the level and duration of fertility in the menstrual cycle. Hum Reprod. 2002;17:1399-403.

255. Mathieu C, Ecochard R, Bied V, Lornage J, Czyba JC. Cumulative conception rate following intrauterine artificial insemination with husband's spermatozoa: influence of husband's age. Hum Reprod. 1995;10:1090-7.

256. Belloc S, Cohen-Bacrie P, Benkhalifa M, Cohen-Bacrie M, De Mouzon J, Hazout $A$, et al. Effect of maternal and paternal age on pregnancy and miscarriage rates after intrauterine insemination. Reprod Biomed Online. 2008;17:392-7.

257. Demir B, Dilbaz B, Cinar O, Karadag B, Tasci Y, Kocak M, et al. Factors affecting pregnancy outcome of intrauterine insemination cycles in couples with favourable female characteristics. J Obstet Gynaecol. 2011;31:420-3.

258. Klonoff-Cohen HS, Natarajan L. The effect of advancing paternal age on pregnancy and live birth rates in couples undergoing in vitro fertilization or gamete intrafallopian transfer. Am J Obstet Gynecol. 2004;191:507-14.

259. ACOG practice bulletin. Management of recurrent pregnancy loss. Number 24, February 2001. (Replaces Technical Bulletin Number 212, September 1995). American College of Obstetricians and Gynecologists. Int J Gynaecol Obstet. 2002;78:179-90

260. de la Rochebrochard E, Thonneau P. Paternal age and maternal age are risk factors for miscarriage; results of a multicentre European study. Hum Reprod. 2002;17:1649-56

261. Kleinhaus K, Perrin M, Friedlander Y, Paltiel O, Malaspina D, Harlap S. Paternal age and spontaneous abortion. Obstet Gynecol. 2006;108:369-77.

262. Slama R, Bouyer J, Windham G, Fenster L, Werwatz A, Swan SH. Influence of paternal age on the risk of spontaneous abortion. Am J Epidemiol. 2005;161:816-23.

263. Luna M, Finkler E, Barritt J, Bar-Chama N, Sandler B, Copperman AB, et al. Paternal age and assisted reproductive technology outcome in ovum recipients. Fertil Steril. 2009:92:1772-5.

264. Ferreira RC, Braga DP, Bonetti TC, Pasqualotto FF, laconelli Jr A, Borges Jr E. Negative influence of paternal age on clinical intracytoplasmic sperm injection cycle outcomes in oligozoospermic patients. Fertil Steril. 2010;93:1870-4.

265. ACOG practice bulletin. Diagnosis and management of preeclampsia and eclampsia. Number 33, January 2002. ACOG Committee on Practice Bulletins-Obstetrics. Obstet. Gynecol. 99:159-67.

266. Harlap S, Paltiel O, Deutsch L, Knaanie A, Masalha S, Tiram E, et al. Paternal age and preeclampsia. Epidemiology. 2002;13:660-7.

267. Dalman C, Allebeck P, Cullberg J, Grunewald C, Koster M. Obstetric complications and the risk of schizophrenia: a longitudinal study of a national birth cohort. Arch Gen Psychiatry. 1999;56:234-40.

268. Spong CY. Defining "term" pregnancy: recommendations from the Defining "Term" Pregnancy Workgroup. JAMA. 2013;309:2445-6.

269. Lawn JE, Gravett MG, Nunes TM, Rubens CE, Stanton C, Group GR. Global report on preterm birth and stillbirth (1 of 7): definitions, description of the burden and opportunities to improve data. BMC Pregnancy Childbirth. 2010;10:S1.

270. Slattery MM, Morrison JJ. Preterm delivery. Lancet. 2002;360:1489-97.

271. Zhu JL, Madsen KM, Vestergaard M, Basso O, Olsen J. Paternal age and preterm birth. Epidemiology. 2005;16:259-62.

272. Astolfi P, De Pasquale A, Zonta LA. Paternal age and preterm birth in Italy, 1990 to 1998. Epidemiology. 2006;17:218-21.

273. Abel EL, Kruger M, Burd L. Effects of maternal and paternal age on Caucasian and Native American preterm births and birth weights. Am J Perinatol. 2002;19:49-54.

274. Olshan AF, Ananth CV, Savitz DA. Intrauterine growth retardation as an endpoint in mutation epidemiology: an evaluation based on paternal age. Mut Res. 1995;344:89-94. 
275. Kinzler WL, Ananth CV, Smulian JC, Vintzileos AM. Parental age difference and adverse perinatal outcomes in the United States. Paediatr Perinat Epidemiol. 2002;16:320-7.

276. Tough SC, Faber AJ, Svenson LW, Johnston DW. Is paternal age associated with an increased risk of low birthweight, preterm delivery, and multiple birth? Can J Public Health. 2003;94:88-92.

277. Hack M, Klein NK, Taylor HG. Long-term developmental outcomes of low birth weight infants. Future Child. 1995;5:176-96.

278. Cartlidge PHT, Stewart JH. Effect of changing the stillbirth definition on evaluation of perinatal mortality rates. Lancet. 1995;346:486-8.

279. Nybo Andersen AM, Hansen KD, Andersen PK, Davey SG. Advanced paternal age and risk of fetal death: a cohort study. Am J Epidemiol. 2004;160:1214-22.

280. Astolfi P, De Pasquale A, Zonta LA. Late paternity and stillbirth risk. Hum Reprod. 2004;19:2497-501.

281. Lin Y-N, Matzuk M. Genetics of Male Fertility. In: Rosenwaks Z, Wassarman PM, editors. Human Fertility, Methods in Molecular Biol, vol. 1154. New York: Springer Protocols, Springer Science+ Business Media; 2014. p. 25-37.

282. Summerer D. Enabling technologies of genomic-scale sequence enrichment for targeted high-throughput sequencing. Genomics. 2009;94:363-8.

283. Montgomery GW, Zondervan KT, Nyholt DR. The future for genetic studies in reproduction. Mol Hum Reprod. 2014;20:1-14.

284. Funaro M. Paduch D. Novel Markers of Male Infertility. In: Fertility H, Rosenwaks Z, Wassarman PM, editors. Methods in Molecular Biol, vol. 1154: Springer Protocols. New York: Springer Science + Business Media; 2014. p. 233-50.

285. Palermo G, Kocent J, Monahan D, Neri Q. Rosenwaks Z. Treatment of Male Infertility. In: Fertility H, Rosenwaks Z, Wassarman PM, editors. Methods in Molecular Biol, vol. 1154: Springer Protocols. New York: Springer Science + Business Media; 2014. p. 385-405.

286. Yuen RK, Merkoulovitch A, MacDonald JR, Vlasschaert M, Lo K, Grober E, et al. Development of a high-resolution Y-chromosome microarray for improved male infertility diagnosis. Fertil Steril. 2014;101:1079-85.

\section{Submit your next manuscript to BioMed Central and take full advantage of:}

- Convenient online submission

- Thorough peer review

- No space constraints or color figure charges

- Immediate publication on acceptance

- Inclusion in PubMed, CAS, Scopus and Google Scholar

- Research which is freely available for redistribution 